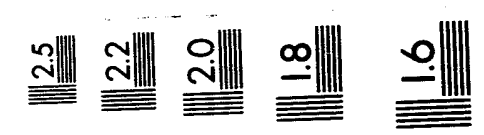

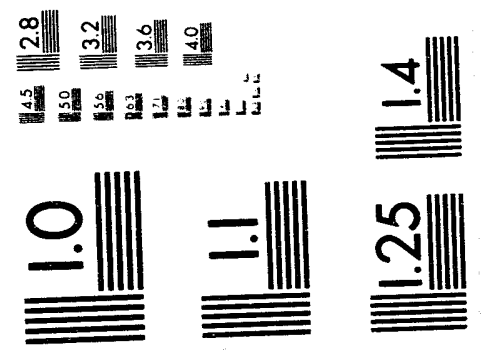



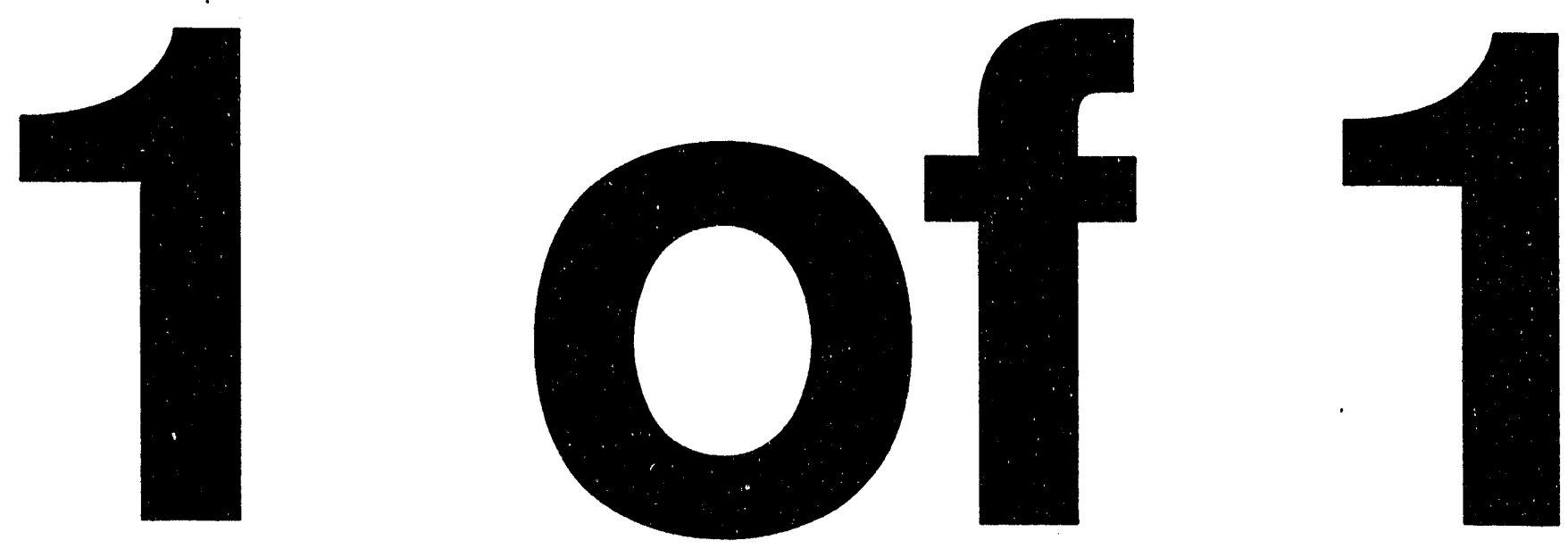
SAND93 -7040

Unlimited Release

UC-72y

9.3,

\section{Individual and Combined Effects of Chloride, Sulfate, and Magnesium lons on Hydrated Portland-Cement Paste}

Toy S. Poole, Lillian D. Wakeley, Cameron L. Young

Structures Laboratory

U.S. Army Corps of Engineers

Waterways Experiment Station

Vicksburg, MS 39180-6199

Prepared by Sandia National Laboratories Albuquerque, New Mexico 87185 and Livermore, California 94550 for the United States Department of Energy under Contract DE-AC04-94AL85000

Printed March 1994 
Issued by Sandia National Laboratories, operated for the United States Department of Energy by Sandia Corporation.

NOTICE: This report was prepared as an account of work sponsored by an agency of the United States Government. Neither the United States Government nor any agency thereof, nor any of their employees, nor any of their contractors, subcontractors, or their employees, makes any warranty, express or implied, or assumes any legal liability or responsibility for the accuracy, completeness, or usefulness of any information, apparatus, product, or process disclosed, or represents that its use would not infringe privately owned rights. Reference herein to any specific commercial product, process, or service by trade name, trademark, manufacturer, or otherwise, does not necessarily constitute or imply its endorsement, recommendation, or favoring by the United States Government, any agency thereof or any of their contractors or subcontractors. The views and opinions expressed herein do not necessarily state or reflect those of the United States Government, any agency thereof or any of their contractors.

Printed in the United States of America. This report has been reproduced directly from the best available copy.

Available to DOE and DOE contractors from Office of Scientific and Technical Information PO Box 62

Oak Ridge, TN 37831

Prices available from (615) 576-8401, FTS 626-8401

Available to the public from

\author{
National Technical Information Service \\ US Department of Commerce \\ 5285 Port Royal Rd \\ Springfield, VA 22161 \\ NTIS price codes \\ Printed copy: A04 \\ Microfiche copy: A01
}


SAND93-7040

Unlimited Release

Distribution

March 1994

Category UC-721

\title{
Individual and Combined Effects of Chloride, Sulfate, and Magnesium Ions on Hydrated Portland-Cement Paste
}

\author{
Toy S. Poole, Lillian D. Wakeley, \\ and Cameron L. Young \\ Structures Laboratory \\ U.S. Army Corps of Engineers \\ Waterways Experiment Station \\ Vicksburg, MS 39180-6199
}

\begin{abstract}
Ground water with a high concentration of magnesium ion is known to cause deterioration to portland cement concretes. A proposed mechanism for this deterioration process published previously involves an approximate 1:1 replacement of $\mathrm{Ca}$ ions by $\mathrm{Mg}$ ions in the crystalline phases of hydrated cement. The current study was undertaken to determine which ions, among magnesium, chloride, and sulfate, cause deterioration; whether their deleterious action is individual or interdependent; and to relate this mechanism of deterioration to the outlook for a 100-yr service life of concretes used in mass placements at the Waste Isolation Pilot Plant.

Loss of $\mathrm{Ca}$ ion by cement pastes was found to be strongly related to the concentration of $\mathrm{Mg}$ ion in simulated ground-water sclutions in which the paste samples were aged. This was true of both saltcontaining and conventional cement pastes. No other ion in the solutions exerted a strong effect on $\mathrm{Ca}$ loss. $\mathrm{Mg}$ ion did not accumulate in the chemically altered cement paste at the same rate that $\mathrm{Ca}$ was lost. Ca-ion loss was more than six times the Mg-ion gain. No crystalline $\mathrm{Mg}$-bearing phases were detected in the deteriorated pastes.

Ca ion left first from calcium hydroxide in the pastes, depleting all calcium hydroxide by 60 days. Some calcium silicate hydrate remained even after 90 days in the solutions with the highest concentration of $\mathrm{Mg}$ ion, while the paste samples deteriorated noticeably. Softening of the samples occurred without complete destruction of calcium silicate hydrate, and with no apparent formation of magnesium silicate hydrate. The results indicated a mechanism that involves dissolution of Ca phases and transport of $\mathrm{Ca}$ ions to the surface of the sample, followed by formation of $\mathrm{Mg}$-bearing phases at this reaction surface rather than directly by substitution within the microstructure of hydrated cement.
\end{abstract}

Given that calcium hydroxide and calcium silicate hydrate are the principal strength-giving phases of hydrated cement, this mechanism indicates the likelihood of significant loss of integrity of a concrete exposed to $\mathrm{Mg}$-bearing ground water at the WIPP. The rate of deterioration ultimately will depend on $\mathrm{Mg}$-ion concentration, the microstructure materials of the concrete exposed to that groundwater, and the availability of brine.

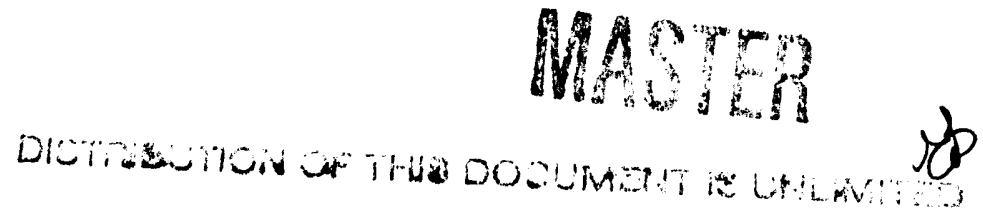




\section{ACKNOWLEDGEMENT}

This work was performed for Sandia National Laboratories (SNL) supported by the U.S. Department of Energy under contract DE-AC04-76DP00789. The performing agency was the Concrete Technology Division (CTD), Structures Laboratory (SL), U.S. Army Engineer Waterways Experiment Station (WES), under SNL Document Number AA 2030. Dr. Lillian D. Wakeley, WES, was Principal Investigator. Dr. Frank Hansen was Project Manager for SNL, in Department 6121, of which Dr. Joe Tillerson is Manager.

Laboratory studies and data analysis for this report were accomplished in the CTD, during April through December 1992. Dr. Steven J. Lambert, SNL, recommended components and proportions for exposure solutions. Mr. John Cook prepared the specimens, Ms. Cameron L. Young managed the experimental exposures and chemical analyses, Dr. Charles A. Weiss, Jr., performed the X-ray diffraction analyses. Dr. Toy S. Poole coordinated laboratory activities and analyzed the data. Dr. Poole and Dr. Lillian Wakeley prepared the report, with assistance from Ms. Young.

This project was completed at the WES under the general supervision of Mr. Bryant Mather, Director, SL; Mr. James T. Ballard, Assistant Director, SL; and Mr. Kenneth L. Saucier, Chief, CTD. Director of WES was Dr. Robert W. Whalin. Commander and Deputy Director was COL Leonard G. Hassell, EN. 


\section{CONTENTS}

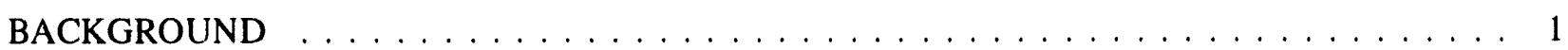

Previous Work at WES Showing Deterioration Associated with Magnesium Ions . . . . . . . 1

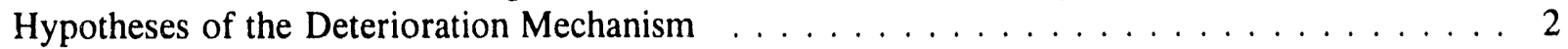

Purpose of the Research Reported Here $\ldots \ldots \ldots \ldots \ldots \ldots$

SELECTION OF MATERIALS AND SPECIMENS $\ldots \ldots \ldots \ldots \ldots \ldots$

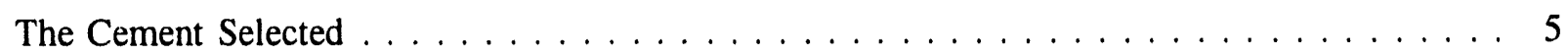

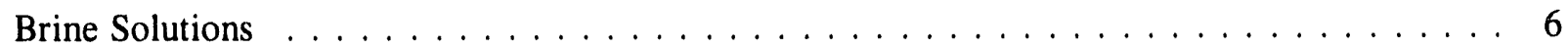

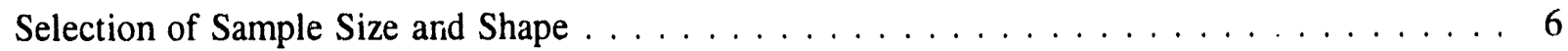

Preparation of Specimens $\ldots \ldots \ldots \ldots \ldots \ldots$

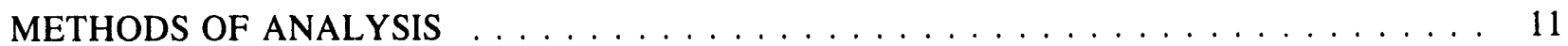

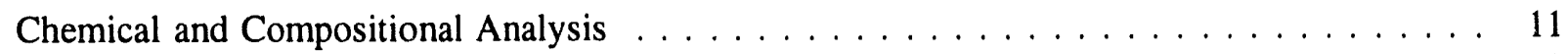

Apparent Changes and Their Correction Factor $\ldots \ldots \ldots \ldots \ldots \ldots$

Statistical Considerations $\ldots \ldots \ldots \ldots \ldots \ldots \ldots$

RESULTS $\ldots \ldots \ldots \ldots \ldots \ldots \ldots \ldots \ldots \ldots \ldots$

Composition of Discs $\ldots \ldots \ldots \ldots \ldots \ldots$

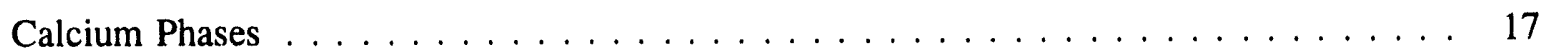

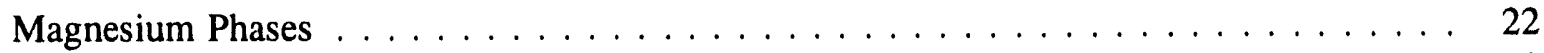

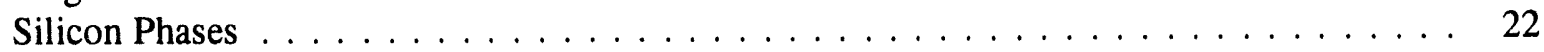

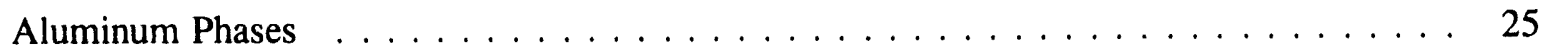

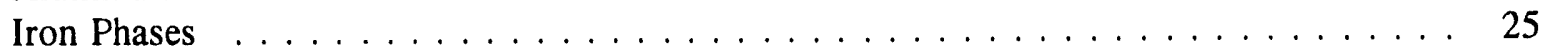



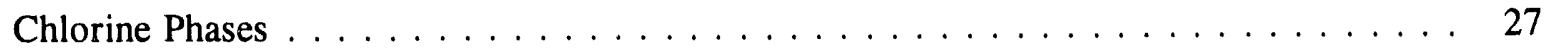

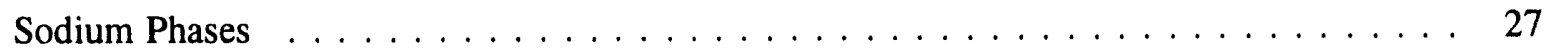

Phase Composition of Precipitates . . . . . . . . . . . . . . . . . . . . . . . . . . . 29



INTEGRATION OF RESULTS $\ldots \ldots \ldots \ldots \ldots \ldots \ldots \ldots$

Relationships between $\mathrm{Ca}^{2+}$ Movement and Other Ions in Solution . . . . . . . . . . 37

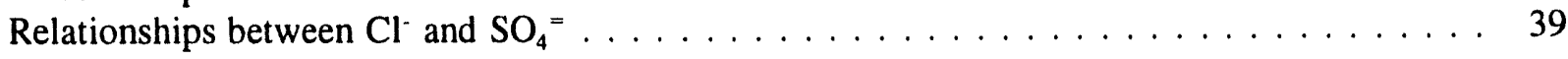

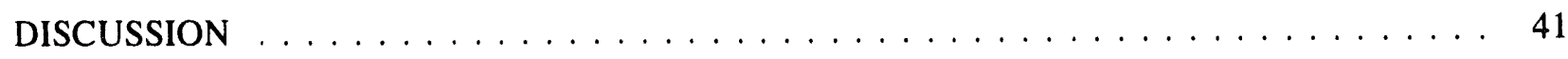

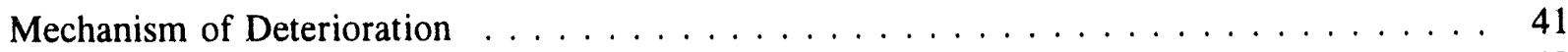

Durability Implications $\ldots \ldots \ldots \ldots \ldots \ldots \ldots \ldots \ldots \ldots$

Approaches to Determining Rate of Deterioration $\ldots \ldots \ldots \ldots \ldots$




APPENDIX A: PROPORTIONS OF SALADO MASS CONCRETE, AND PROPERTIES OF CEMENT AND STANDARD BRINE . . . . . . . . A-1

APPENDIX B: DESCRIPTION OF SURFACE DEPOSITS ON DISCS AFTER 60 DAYS EXPOSURE TIME

APPENDIX C: UNCORRECTED AND Fe-CORRECTED CHEMICAL ANALYSIS OF DISCS

\section{Figures}

1. Percentage of $\mathrm{CaO}$ remaining in non-salt paste specimens $\ldots \ldots \ldots \ldots \ldots$

2. Percentage of $\mathrm{CaO}$ remaining in salt paste specimens $\ldots \ldots \ldots \ldots \ldots \ldots$

3. Percentage of $\mathrm{MgO}$ accumulated in non-salt specimens vs. exposure time $\ldots \ldots \ldots \ldots$

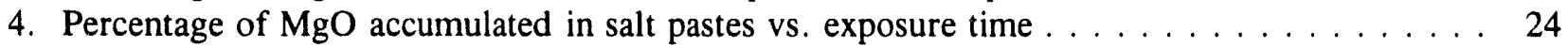



6. Total chloride in cement pastes after 90 days in solutions $\ldots \ldots \ldots \ldots \ldots$

7. Photograph of specimen exposed to solution 1 for 90 days $\ldots \ldots \ldots \ldots \ldots$

8. Photograph of specimen exposed to solution 2 for 90 days $\ldots \ldots \ldots \ldots \ldots$

9. Molar ratio of $\mathrm{Ca}$ loss to $\mathrm{Mg}$ gain vs. exposure time $\ldots \ldots \ldots \ldots$

\section{Tables}

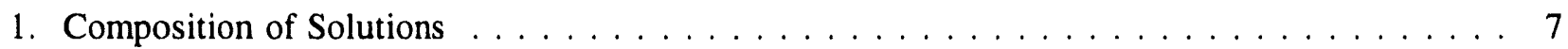

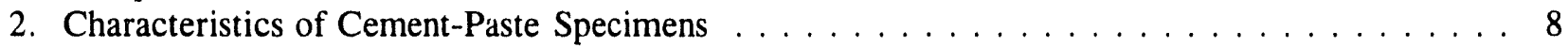

3. Estimates of Experimeital Error Associated with Corrected Oxide Analysis . . . . . . . . . . 14

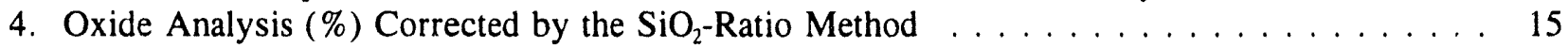

5. Crystalline Phases Detected by X-ray Diffraction in Pastes after Exposure to Solution . . . . 18

6. Loss Rates of $\mathrm{CaO}$ Estimated from Linear Regression . . . . . . . . . . . . . . . . . . 21

7. XRD Analysis of Surface Precipitates after 60 and 90 Days in Solution . . . . . . . . . . 30

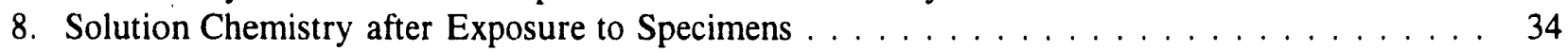




\section{BACKGROUND}

The Waste Isolation Pilot Plant (WIPP) is a research and development facility of the U.S. Department of Energy. Its purpose is to demonstrate safe disposal of radioactive wastes from U.S. Defense activities. For nearly 20 years, the U.S. Army Engineer Waterways Experiment Station (WES) has provided research support to Sandia National Laboratories (SNL) involving cement-based grouts and concretes proposed for use in the WIPP facility.

One of the objectives of this research support at WES in recent years has been to develop concrete for use in the WIPP at the proposed repository horizon, and determine experimentally whether it will be durable for the approximate 100-yr operating life of the facility. Ground waters at the WIPP facility horizon (656 $\mathrm{m}$ underground) and close above it include high concentrations of a variety of ions, some of which are known to cause deterioration and loss of strength in hardened concrete in many environments. Most notable of these ions in WIPP ground waters are magnesium, sulfate, and to a lesser degree, chloride (Lambert et al., 1992).

\section{Previous Work at WES Showing Deterioration Associated with Magnesium lons}

In 1990, 5-yr-old concrete in the liner of the WIPP waste-handling shaft was found to have deteriorated. One major conclusion from these studies was that observed deterioration was related to high magnesium ion levels in the ground water (Wakeley et al., 1992; Lankard, 1990). Following this study, laboratory work was initiated at the WES to determine the extent to which some of the concrete mixtures and materials being considered for use at the WIPP were adversely affected by a simulated, worst-case, high-magnesium ion ground water. The simulated ground water used for that research was formulated by Lambert and designated H-IRSCM. Its composition was reported by Wakeley et al. (1992).

The results of the laboratory work had indicated that all of the mixtures under test were sensitive to H-1RSCM to varying degrees. The mechanism of deterioration was not identified because of the complex chemical compositions of both the brine and the cement-based mixtures chosen for study. Because the simulated ground water was highly concentrated in magnesium (Mg), sulfate, and chloride ions, it was difficult to tell which of these was causing most of the damage. The cementitious materials were mixtures of portland cement, with and without different fly ashes and 
shrinkage-compensating components. These different cementitious or pozzolanic components gave each mixture a complex initial phase assemblage. The cement and fly ash each was a source of the hydrated phases with potential to react with $\mathrm{Mg}$. The dolomitic aggregates also had been deteriorated, had lost strength, and could have contributed to the reaction products identified from this concrete.

While it was clear from the studies involving $\mathrm{H}-1 \mathrm{RSCM}$ that $\mathrm{Mg}$ ion was a factor in deterioration and loss of strength of these cementitious systems, it also was clear that studies of more simplified systems were more likely to reveal the mechanism of deterioration. It is important to know the mechanism, first so that the chemical threat to concrete performance, if any, is understood; and second, understanding of the mechanism is a tool to use in formulating materials systems with improved resistance to deterioration or identifying other necessary engineered harriers.

\section{Hypotheses of the Deterioration Mechanism}

Earlier conclusions about the effect of $\mathrm{Mg}$ on hardened cement paste, which is the strengthgiving component of concrete, were derived from work on sulfate-attack problems and other forms of chemical deterioration of reinforced concrete in contact with sea water. Magnesium is a significant component of seawater, and its potential to initiate chemical changes to cement paste has been reported widely (Mather, 1966; Buck et al., 1984; Massazza, 1985; Bonen and Cohen, 1992).

There has been some research on the effects of other $\mathrm{Mg}$ salts (Biczok, 1972; Ftikos and Parissakis, 1985; Helmy et al., 1991; Kuenning, 1966; Oberst-Padtberg, 1985; Smolczyk, 1968), although this subject commonly has been a side issue to a study with some other focus. The deterioration mechanism for the action of magnesium has been proposed as a two-step process.

First, water containing magnesium ions penetrates into the hardened paste and precipitates as magnesium hydroxide $(\mathrm{MH})$ when it encounters the high-pH pore fluid which is a saturated solution of calcium hydroxide $(\mathrm{CH})$. Most of the calcium hydroxide exists in the solid state. Calcium (Ca) is solubilized from solid calcium hydroxide by a reaction between calcium hydroxide and magnesium ions and can diffuse out of the paste if a concentration gradient exists. The following reaction illustrates this process: 


$$
\mathrm{Ca}(\mathrm{OH})_{2}[\text { solid }]-\mathrm{Ca}^{2+}+2 \mathrm{OH}^{1-}+\mathrm{Mg}^{2+}[\text { solution }]-\mathrm{Mg}(\mathrm{OH})_{2}+\mathrm{Ca}^{2+}
$$

Since $\mathrm{MH}$ is very insoluble, its precipitation depletes $\mathrm{OH}^{-}$from solution, causing more $\mathrm{CH}$ to dissolve to maintain the pore fluid in a saturated condition. Consequently, $\mathrm{CH}$ in the solid state can become severely depleted. $\mathrm{MH}$ occupies a larger volume than the $\mathrm{CH}$ it replaces, causing microfractures in the paste and allowing further entry of aggressive fluids.

The second step of the proposed mechanism continues as $\mathrm{Mg}$ enters an exchange reaction for the $\mathrm{Ca}$ in calcium silicate hydrate (CSH), eventually forming magnesium silicate hydrate (MSH), which is non-cementitious. The following reaction approximates the case of sea water, where the sulfate ion is important (Mather, 1966).

$$
\begin{gathered}
3 \mathrm{CaO} \cdot 2 \mathrm{SiO}_{2} \cdot n \mathrm{H}_{2} \mathrm{O}+\mathrm{MgSO}_{4}-\mathrm{CaSO}_{4} \cdot 2 \mathrm{H}_{2} \mathrm{O}+\mathrm{Mg}(\mathrm{OH})_{2}+\mathrm{SiO}_{2} \cdot n \mathrm{H}_{2} \mathrm{O} \\
4 \mathrm{Mg}(\mathrm{OH})_{2}+\mathrm{SiO}_{2} \cdot n \mathrm{H}_{2} \mathrm{O}-4 \mathrm{MgO} \cdot \mathrm{SiO}_{2} \cdot 8.5 \mathrm{H}_{2} \mathrm{O}+(n-4.5) \mathrm{H}_{2} \mathrm{O}
\end{gathered}
$$

There may also be secondary effects due to the anions in the brine, which may not be covered by above reactions. Sulfate and chloride ions react with aluminates in the cement paste to form calcium sulfoaluminate and calcium chloroaluminate, respectively. Both of these compounds have the potential to be destructive, depending on how and when they form in the paste. These secondary effects could exacerbate the hypothesized primary effect of magnesium on calcium silicate hydrate.

This proposed two-step deterioration process, though plausible, was not confirmed by analyses of the reaction products from H-IRSCM brine and various cementitious solids. There was very little, if any, direct evidence that MSH or other magnesium-bearing compounds had formed in the deteriorated solids (Wakeley et al., 1992). And there was no compelling evidence that the sulfates in the simulated ground water were causing any serious degradation, although sulfate attack had been proposed as a deterioration mechanism for the WIPP waste-shaft-liner concrete (Lankard, 1991).

\section{Purpose of the Research Reported Here}

This work was undertaken to identity mechanisms of deterioration of cement paste caused by magnesium, chloride, and sulfate, and to determine whether the deleterious effects of these ions are 
individual or interdependent. A further purpose was to relate mechanisms of deterioration to the likelihood that a mass concrete will serve as intended for the 100 -yr operating life of the repository.

The presence of brines with abundant magnesium, sulfate and chloride in the Salado Formation creates a potentially difficult service environment for portland-cement concretes to be used as seal components. Concrete is the most practical material to use for large-scale load-bearing members of the seal system. If the concrete could be placed in brine-free regions of the repository' where no brine is present, the potential for chemical deterioration would be minimal. However, brines can migrate. Also, load-bearing members may be required in areas where brines are unavoidable. Therefore, the nature and likelihood of interactions between concrete and brine control the potential for acceptable service. 


\section{SELECTION OF MATERIALS AND SPECIMENS}

The basis for selection of materials for the experimental matrix was twofold. First, materials used for fabricating specimens had to be related directly to the overall WIPP materials research program at the WES. The research on geochemical stability of cement-based seals needs to provide information useful to the research and development of candidate concretes. Therefore, it must involve materials that are realistic candidates for concrete components. For this reason, cements with no tricalcium aluminate $\left(C_{3} A\right)$ were not considered because they are not readily available. Those with a high percentage of $\mathrm{C}_{3} \mathrm{~A}$ were omitted from consideration because of their susceptibility to several forms of chemical attack in this environment.

The second basis for selection of materials was the need to keep the system simple enough that reaction products could be related to reaction mechanisms between portland cement and brine components. Fly ash and shrinkage-compensating admixtures were omitted from the pastes in the experimental matrix, even though both materials are included in the current candidate concrete. This was to remove any question of the source of the reacted phases, by having only a single source (cement) for the hydrated phases susceptible to reaction with magnesium ions.

\section{The Cement Selected}

The cement selected was a Class $\mathrm{H}$ oilwell cement. The WES has a successful history of using this cement in grouts and concretes for underground containment systems (Gulick and Wakeley, 1989; Wakeley, 1990). It is a major cementitious component of the Salado Mass Concrete, the mass concrete formulation currently recommended by WES for WIPP panel seals (Appendix A).

Oilwell cement is basically a portland cement that has been chemically and physically formulated to allow extended working time under conditions of elevated temperature and pressure (Smith, 1990). The most obvious difference between oilwell cements and conventional portland cements is the relatively coarser particle size distribution of oilwell cements. Also, this particular cement was formulated to be resistant to chemical interaction with high levels of sulfate ion in its service environment. Chemical and physical properties of the cement are summarized in Appendix A. 


\section{Brine Solutions}

Published work on concrete in seawater (references given p. 2) and WES experience indicate that magnesium, sulfate, and chloride have strong potential to initiate deterioration of hydrated cement phases in environments where concrete is in contact with waters containing dissolved salts. These were the ions of interest in the matrix of solutions.

Because of charge-balance constraints, encentrations of magnesium, sulfate, and chloride ions could not be varied in completely independent ways without introducing other ions. This would have required assumptions about the action of or interactions with the additional ions, which were precluded by the need for simplicity. Therefore, the solution matrix was selected to create wide but controlled variation within the corstraints allowed by sodium and magnesium, present in the solutions initially as sulfate and chloride salts. The solution matrix was established by joint effort of SNL and WES researchers, with ion concentrations recommended by SNL.

All solutions in the matrix contained some concentration of each of the three ions of principal interest. This simulates reality in that ground waters in the vicinity of the WIPP contain some concentration of these ions. Brine compositions, based on analyses of waters from the Rustler Formation, are described in Table 1. Relative concentrations of each of the three major ions are designated as "H," representing the highest concentration expected in ground water; "M," representing moderate concentrations; and "L," representing the lowest concentration expected. The range of concentrations varied over two orders of magnitude. This was intended to reveal whether or not there is a threshold effect, that is, a concentration of $\mathrm{Mg}$ or other critical ion below which it is not a serious problem. Also, it was intended to reveal whether each ion presents a potential for chemical interaction with cement individually, or only in combination with one or more of the other critical ions.

\section{Selection of Sample Size and Shape.}

Another goal of the experimental design was to use a specimen configuration that would cause must of the volume of each specimen to undergo the prevailing reactions in a manageable length of time without being artificially accelerated by heat or other means. In the previous work, we had used 


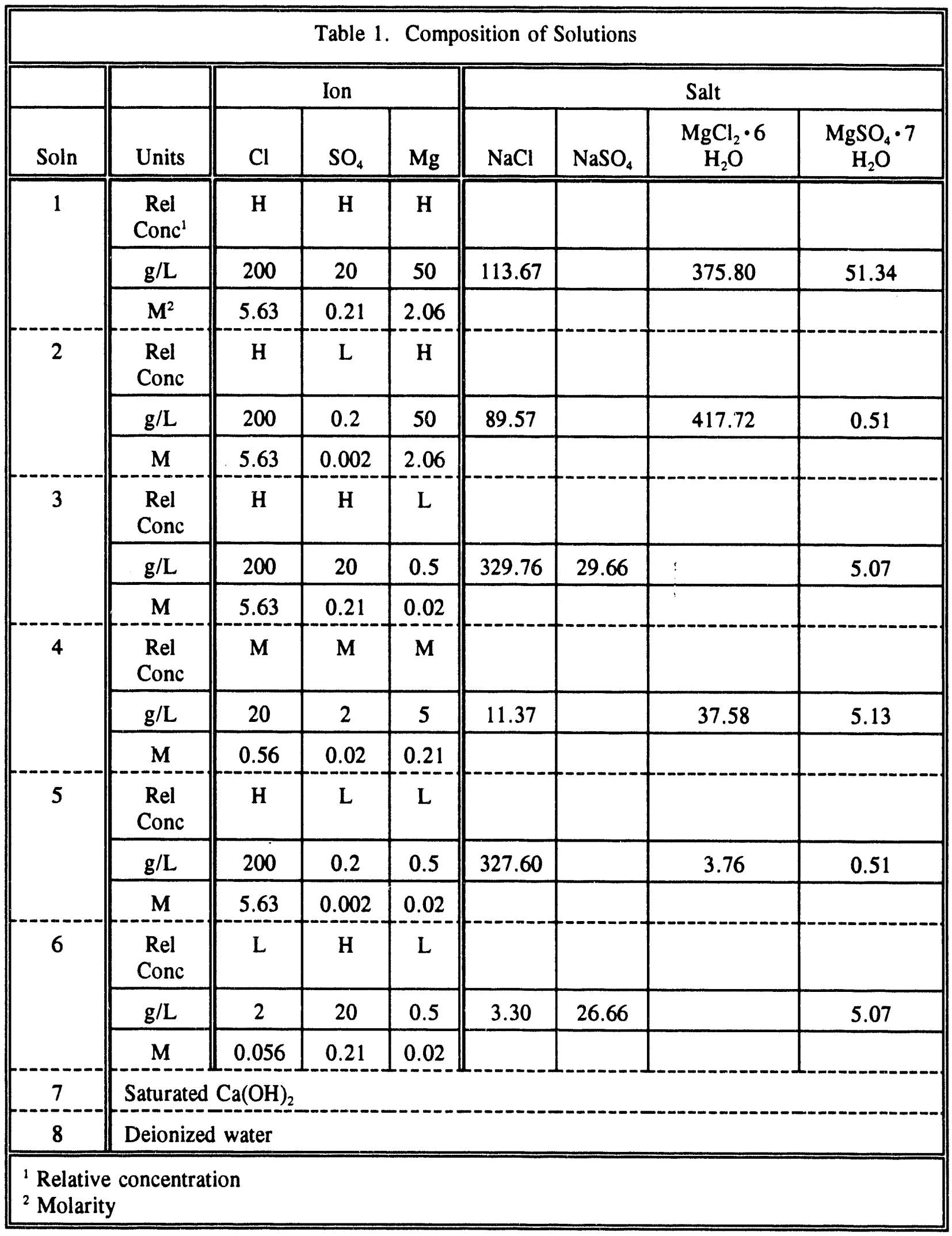


2-in. cubes immersed in brine, which resulted in reaction gradients inward from the outside of each cube. This zoning caused complications in carrying out the post-treatment chemical analyses: from an analytical viewpoint, each zone was a separate sample. To avoid this diffusion-controlled zoning in the present study, relatively thin disc specimens of hardened paste were exposed to each solution. If deterioration was active, each specimen could be expected to undergo chemically controlled deterioration throughout its small thickness during a relatively short exposure time and at a temperature representative of the proposed repository.

Discs $3 \mathrm{~mm}$ thick were chosen to achieve the goal of total-volume reactivity. Samples thinner than this were not expected to have sufficient strength after the reactions to remain intact during handling, photography, and preparation for analysis. With this small sample size, however, we could not use compressive strength measurements to monitor the reactions by strength loss. Monitoring progress of reactions by presence of $\mathrm{Mg}$-bearing phases also was not reasonable, given that such phases had not been positively identified as replacing cement paste. Results of the work involving 2-in. cubes had indicated that deteriorated zones always lost calcium (Wakeley et al., 1992). With total reaction of each sample in the present study, changes in the composition of discs could be monitored by X-ray diffraction (XRD) and by non-destructive bulk chemical analysis using energydispersive X-ray fluorescence (bulk XRF). Changes indicated by analyses of solids could be crosschecked by concomitant changes in brine composition, and phase composition of precipitates. Characteristics of cement-paste specimens are summarized in Table 2.

Table 2. Characteristics of Cement-Paste Specimens

\begin{tabular}{ll}
\hline \multicolumn{1}{c}{ Property } & \multicolumn{1}{c}{ Description } \\
\hline Cement & Class H Oilwell Cement \\
Water-Cement Ratio, by mass & 0.40 \\
Mixing Water & $\begin{array}{l}\text { a) saturated } \mathrm{NaCl} \text { solution ("salt") } \\
\text { b) deionized water ("non-salt") }\end{array}$ \\
Disc Diameter & $20 \mathrm{~mm}$ \\
Disc Thickness & $3.0 \mathrm{~mm}$ \\
Mass of typical disc & 2.2 grams \\
\hline
\end{tabular}




\section{Preparation of Specimens}

Cement pastes were mixed according to ASTM C 305. Two types of pastes were prepared: 1) using deionized water for mixing, designated "non-salt"; and 2) made with mixing water saturated with sodium chloride, designated "salt." The salt-saturated condition is more meaningful to the overall project needs, given that the candidate Salado Mass Concrete is salt-saturated. The non-salt mixtures were included in the study because of anticipated questions about the effects on long-term durability of initial salt-saturation of concrete. Also, they were expected to contribute to understanding the mechanism of deterioration.

Pastes were cast in 20 - by $70-\mathrm{mm}$ plastic vials with snap caps, and were cured at $80^{\circ} \mathrm{F}$ (simulating field temperature) for 30 days in these vials. Selection of 30 days as the age of pastes when tests were initiated was arbitrary but reasonable. Given that properties of cement-based materials are time dependent, the age of the cement paste when specimens were first immersed in the test solutions could alter the rate of reactions, but not the fact that reactions occur. Exposing the samples to brines at a very early age -- i.e. during setting and soon after -- did not seem necessary for simulating field conditions. In panel seals or bulkheads, it is unlikely that brine will participate in initial hydration reactions. Brine movement at the proposed repository horizon is very slow (Krumhansl et al., 1991) and it is unlikely that a significant quantity of brine would arrive at the interface between concrete and host rock early enough to affect formation of initial hydration products. Thirty days was selected as a reasonable age by which concrete in a panel seal might be exposed to a significant quantity of ground water.

After the 30 days of curing in vials, paste cylinders were demolded and cut into 3-mm-thick discs with a diamond-bladed saw, using a light oil as a lubricant. Discs were cleaned with acetone to remove the oil, and allowed to air dry for 24 hours. Some pastes were left in the molds and later demolded and cut for analysis as control specimens.

Individual discs were randomly selected and each was immersed in one of the eight exposure solutions. Volume of solution was $30 \mathrm{~mL}$, which was calculated to give a ratio of magnesium ion in solution to $\mathrm{Ca}$ ion in the paste of at least 10 , for solutions having high $(\mathrm{H}) \mathrm{Mg}$ concentration. This was intended to insure that lack of available magnesium did not become a reaction-limiting factor during the experiment. 


\section{METHODS OF ANALYSIS}

\section{Chemical and Compositional Analysis}

Discs were removed from the solutions after 14, 30, 60, and 90 days of immersion. The discs removed after 14-day exposure were used for development of techniques of sample preparation and analytical methods. Consequently, data from this early age are not reported. Discs from most solutions were covered with a white precipitate, or crystalline growth, at all ages. Surface deposits are described in Appendix B. This surface coating was scraped off and saved for X-ray diffraction (XRD) analysis. Discs were then processed and analyzed for elemental composition by X-ray fluorescence (XRF), and for mineralogical composition by XRD, as described below. Compositions of residual brine solutions also were analyzed by XRF. The following paragraphs describe sample preparation and analyses.

Precipitates were removed from the surface of each disc with a razor blade. The remaining residue of precipitate was sanded off using $14.5-\mu \mathrm{m}$ aluminum oxide powder. Each disc was then washed with methanol in an ultrasonic cleaner for about 30 seconds. After washing with acetone and drying in air, the disc was labeled and vacuum dried for 48 hours, to achieve constant mass and stop reactions.

For XRD analysis, a portion of each disc sample was ground to pass a $45-\mu \mathrm{m}$ sieve and loaded into a sample holder as a random powder mount. Samples of surface precipitates were mounted as slurries. XRD patterns were collected from samples in air at room temperature, using a Philips APD 1700 system, operated from 2 to $70^{\circ} 2 \theta$ using $\mathrm{Cu}$ radiation and a scan rate of $2^{\circ} 2 \theta$ per minute.

For elemental analysis, the portion of the disc used for XRD was recovered and combined with the rest of the disc. These were ground to pass a $45-\mu \mathrm{m}$ sieve and ignited at $900^{\circ} \mathrm{C}$ for 15 minutes. The sample was uniformly combined with boric acid (4:1), as a binder. Each sample was pressed into a pellet using an hydraulic press, to be analyzed using XRF. The backing of the pellet consisted of $4.0 \mathrm{~g}$ of boric acid.

These samples were analyzed on a Kevex energy dispersive $\mathrm{X}$-ray fluorescence spectrometer using the Energy-dispersive X-ray Analysis Technique (EXACT). This procedure was developed by Harmon et al. (1978), as referenced by Kevex Instruments (1990), and is included as part of the 
Kevex proprietary software, "Toolbox" (Kevex Instruments, 1990). The procedure combines the use of fundamental parameters with the known composition of a single standard. The standard was a sample of a disc that had not been exposed to any solution, and prepared as described above. The composition of this standard was determined as described in ASTM C 114, using atomic absorption, gravimetric, and volumetric techniques. By convention, elemental-analysis results are expressed as oxides.

Compositions of brine solutions also were analyzed by XRF. One $\mathrm{mL}$ of solution was placed in a plastic cup the bottom of which was a thin film of mylar. A small watch glass was placed over the cup to prevent evaporation. The system was flushed with helium. The EXACT procedure also was used for these analyses, with a brine solution of known composition as a standard. The composition of this standard solution is summarized in Appendix A. Solutions were analyzed at 14 through 60 days without modification. At 90 days, solutions were acidified with $\mathrm{HCl}$, when it was apparent that the solutions were clouded with suspended solids. Heterogeneous samples such as these can cause bias in results, as discussed later (see Results).

\section{Apparent Changes and Their Correction Factor}

Comparison of oxide compositions among conditions from simple elemental analysis can result in misleading conclusions. As a result of exposure to salt-bearing solutions, some of the specimens either gained or lost chemical species, or both. This resulted in a net mass change. Because oxides are determined as percentages of the total mass, the relative amounts of some oxides would change as a result of mass loss or gain to the specimen, even if none of that particular oxide was gained or lost from the paste. For example, if $\mathrm{NaCl}$ enters a sample of paste during exposure to solution, but nothing leaves the paste, the analyzed composition of that paste will show a relative decrease in all of the other components. The apparent loss will be proportional to the mass increase associated with the $\mathrm{NaCl}$. Therefore, the solid being analyzed would appear to have lost $\mathrm{Ca}$, even though none actually left the system.

A direct way to compensate for this effect would be to measure mass changes of the specimens and to correct accordingly. This direct determination of mass change was not possible because of the precipitates that formed on the surfaces of each disc and the physical abrasion required to remove 
them. Instead, we chose to use the apparent amount of a non-mobile oxide as a basis for a correction procedure, as described below.

Analysis of solution chemistry showed that neither $\mathrm{SiO}_{2}$ nor $\mathrm{Fe}_{2} \mathrm{O}_{3}$ were lost from the pastes as a result of exposure to any of the solutions. This is consistent with other analyses of concretes exposed to natural brines. Therefore, it is reasonable to assume that changes in apparent composition of either of these oxides represents mass changes in the specimen, rather than any real gain or loss of $\mathrm{Fe}$ or $\mathrm{Si}$. This became the basis of a correction factor, which then was applied to the other oxide compositions to identify real changes in percentages of other oxides.

The correction factor was calculated as the ratio of the value of the indicator oxide (either $\mathrm{SiO}_{2}$ or $\mathrm{Fe}_{2} \mathrm{O}_{3}$ ) determined under control conditions, to the value after the experimental exposure. No mass changes could have occurred under control conditions because samples were sealed in piastic vials. A value less than unity indicates mass loss from the system. The following equation represents the correction,

$$
A_{c}=A \cdot\left[\frac{B_{\text {control }}}{B_{\text {exposed }}}\right]
$$

where $A_{c}$ is the corrected value of the oxide in question, $A$ is the value of that oxide obtained from a simple elemental analysis, $\mathrm{B}_{\text {conrod }}$ is the value of $\mathrm{SiO}_{2}$ or $\mathrm{Fe}_{2} \mathrm{O}_{3}$ of the control specimen, and $\mathrm{B}_{\text {expased }}$ is the value of $\mathrm{SiO}_{2}$ or $\mathrm{Fe}_{2} \mathrm{O}_{3}$ after exposure to solution. Two different correction factors were calculated, one each based on $\mathrm{SiO}_{2}$ and $\mathrm{Fe}_{2} \mathrm{O}_{3}$. The values compared favorably. Values for the $\mathrm{SiO}_{2}-$ based correction are in Table 4. $\mathrm{Fe}_{2} \mathrm{O}_{3}$-based correction factors are in Appendix $\mathrm{C}$.

\section{Statistical Considerations}

Results from each experimental condition represent a single replicate, so it is not possible to calculate experimental error limits directly from results for each condition. Given that the experiments were intended to reveal time-dependent trends and not compare individual data points, this was not considered a problem. However, there are instances when this kind of direct comparison of single results from two different conditions is useful. In these instances, it is important to have an estimate of the size of the random error component of the experiment. 
An estimate of experimental error can be obtained from the analysis of the controls. Both the salt and the non-salt control specimens were analyzed on 3 occasions. Because these controls were sealed in plastic vials, their composition was assumed to be constant and the three analyses are taken as independent replicates. Variation among these replicates gives an estimate of experimental error based on 4 degrees of freedom. These estimates, along with $95 \%$ confidence intervals associated with the single observation typical of the remainder of the data, are in Table 3.

Table 3. Estimates of Experimental Error Associated with Corrected Oxide Analysis

\begin{tabular}{ccc}
\hline Analyte & $\begin{array}{c}\text { Std. Dev. estimated } \\
\text { from controls }\end{array}$ & $\begin{array}{c}\text { 95\% Confidence Intervals, } \\
\text { single observations }\end{array}$ \\
\hline $\mathrm{CaO}$ & 3.47 & 9.64 \\
$\mathrm{MgO}$ & 0.04 & 0.10 \\
$\mathrm{SiO}_{2}$ & 1.86 & 5.16 \\
$\mathrm{SO}_{4}$ & 0.13 & 0.37 \\
$\mathrm{Cl}$ & 0.76 & 2.11 \\
$\mathrm{Al}_{2} \mathrm{O}_{3}$ & 0.09 & 0.25 \\
$\mathrm{Na}_{2} \mathrm{O}$ & 0.90 & 2.49
\end{tabular}

If two values differ by more than the amount of the $95 \%$ confidence interval, then the difference is probably larger than would be attributable to random error. For example, the $\mathrm{CaO}$ level in paste specimens made with salt and exposed to solution 1 for 90 days was $37.29 \%$ (see observation 3, in Table 4). The $\mathrm{CaO}$ levels of a similar specimen exposed for 90 days to solution 3 was 30.45 (see observation 6, Table 4). Whereas both of the values are considerably below the initial $\mathrm{CaO}$ condition, the $6.85 \%$ difference between them is reasonably to be expected from random error, so these data cannot be taken as conclusive evidence of a difference in effects on the cement paste of solutions 1 and 2 . 


\begin{tabular}{|c|c|c|c|c|c|c|c|c|c|c|}
\hline OBS $^{1}$ & $\mathrm{COND}^{2}$ & AGE & $\mathrm{CaO}$ & $\mathrm{MgO}$ & $\mathrm{Fe}_{2} \mathrm{O}_{3}$ & $\mathrm{SO}_{4}$ & $\mathrm{Cl}$ & $\mathrm{Al}_{2} \mathrm{O}_{3}$ & $\mathrm{Na}_{2} \mathrm{O}$ & $\mathrm{CF}^{3}$ \\
\hline 1 & 1S & 30 & 45.90 & 1.45 & 3.44 & 2.77 & 9.82 & 3.34 & 4.30 & 0.868 \\
\hline 2 & 1S & 60 & 41.02 & 1.72 & 3.75 & 2.75 & 8.59 & 3.66 & 1.68 & 0.807 \\
\hline 3 & $1 \mathrm{~S}$ & 90 & 37.29 & 1.86 & 3.74 & 3.14 & 10.20 & 3.65 & 4.00 & 0.758 \\
\hline 4 & $2 S$ & 30 & 44.45 & 1.59 & 3.44 & 2.49 & 10.13 & 3.36 & 4.55 & 0.840 \\
\hline 5 & $2 S$ & 60 & 38.71 & 2.68 & 3.88 & 2.16 & 8.25 & 3.67 & 1.72 & 0.784 \\
\hline 6 & $2 S$ & 90 & 30.45 & 5.14 & 3.44 & 2.05 & 8.47 & 3.77 & 2.80 & 0.675 \\
\hline 7 & $3 S$ & 30 & 57.41 & 1.28 & 3.48 & 3.69 & 7.63 & 3.28 & 5.96 & 0.998 \\
\hline 8 & $3 S$ & 60 & 57.51 & 1.34 & 3.69 & 3.35 & 7.38 & 3.46 & 5.71 & 0.998 \\
\hline 9 & $3 S$ & 90 & 54.50 & 1.26 & 3.34 & 3.72 & 7.11 & 3.47 & 5.41 & 0.933 \\
\hline 10 & $4 S$ & 30 & 43.84 & 1.25 & 3.17 & 4.10 & 2.99 & 3.26 & 0.65 & 0.761 \\
\hline 11 & $4 S$ & 60 & 45.45 & 1.32 & 3.43 & 3.56 & 2.06 & 3.43 & 0.33 & 0.777 \\
\hline 12 & $4 S$ & 90 & 41.78 & 1.26 & 3.16 & 3.94 & 3.94 & 3.53 & 0.31 & 0.714 \\
\hline 13 & $5 \mathrm{~S}$ & 30 & 54.78 & 1.23 & 3.25 & 1.36 & 6.91 & 3.23 & 2.64 & 0.928 \\
\hline 14 & $5 S$ & 60 & 56.50 & 1.21 & 3.66 & 0.88 & 6.80 & 3.43 & 2.62 & 0.983 \\
\hline 15 & $5 S$ & 90 & 52.37 & 1.14 & 3.13 & 0.95 & 6.80 & 3.40 & 2.54 & 0.880 \\
\hline 16 & $6 S$ & 30 & 53.21 & 1.20 & 3.18 & 6.37 & 1.01 & 3.13 & 0.81 & 0.893 \\
\hline 17 & $6 S$ & 60 & 55.24 & 1.24 & 3.46 & 6.61 & 0.63 & 3.29 & 0.72 & 0.933 \\
\hline 18 & $6 S$ & 90 & 51.19 & 1.20 & 3.14 & 7.05 & 0.59 & 3.32 & 1.20 & 0.836 \\
\hline 19 & $7 \mathrm{~S}$ & 30 & 53.42 & 1.16 & 3.00 & 2.04 & 1.40 & 3.17 & 0.45 & 0.848 \\
\hline 20 & $7 S$ & 60 & 54.75 & 1.20 & 3.22 & 1.95 & 1.15 & 3.33 & 0.13 & 0.876 \\
\hline 21 & $7 S$ & 90 & 52.51 & 1.13 & 3.06 & 2.10 & 0.98 & 3.43 & 0.10 & 0.822 \\
\hline 22 & $8 \mathrm{~S}$ & 30 & 56.44 & 1.20 & 3.36 & 2.08 & 1.51 & 3.21 & 0.36 & 0.910 \\
\hline 23 & $8 \mathrm{~S}$ & 60 & 54.05 & 1.21 & 3.27 & 1.96 & 1.15 & 3.33 & 0.13 & 0.872 \\
\hline 24 & $8 S$ & 90 & 48.49 & 1.19 & 2.84 & 2.07 & 1.12 & 3.46 & 0.25 & 0.752 \\
\hline 25 & CS & 30 & 53.06 & 1.24 & 3.24 & 2.17 & 7.17 & 3.32 & 4.66 & 0.947 \\
\hline 26 & CS & 60 & 58.60 & 1.31 & 3.54 & 2.19 & 7.89 & 3.43 & 5.06 & 1.032 \\
\hline 27 & $\mathrm{CS}$ & 90 & 58.27 & 1.26 & 3.41 & 2.45 & 9.23 & 3.39 & 7.02 & 1.026 \\
\hline & & & & & & & & & \multicolumn{2}{|c|}{ (Continued) } \\
\hline $\begin{array}{ll}1 & \mathrm{Ob} \\
2 & \mathrm{Ex} \\
3 & \mathrm{CF} \\
\end{array}$ & $\begin{array}{l}\text { on } n \\
\text { cond }\end{array}$ & fro & tisti & lysi & $\begin{array}{l}\text { are } \\
\text { sal }\end{array}$ & $\begin{array}{l}\text { fer } \\
\text { or }\end{array}$ & $\begin{array}{r}\text { sp } \\
(\mathrm{N} \\
\text { ndix } \\
\end{array}$ & res & & \\
\hline
\end{tabular}




\begin{tabular}{|c|c|c|c|c|c|c|c|c|c|c|}
\hline OBS $^{\prime}$ & $\mathrm{COND}^{2}$ & AGE & $\mathrm{CaO}$ & $\mathrm{MgO}$ & $\mathrm{Fe}_{2} \mathrm{O}_{3}$ & $\mathrm{SO}_{4}$ & $\mathrm{Cl}$ & $\mathrm{Al}_{2} \mathrm{O}_{3}$ & $\mathrm{Na}_{2} \mathrm{O}$ & $\mathrm{CF}^{3}$ \\
\hline 1 & $1 \mathrm{~N}$ & 30 & 51.30 & 1.66 & 3.83 & 3.73 & 8.60 & 3.97 & 2.57 & 0.943 \\
\hline 2 & $1 \mathrm{~N}$ & 60 & 49.10 & 2.29 & 4.09 & 3.99 & 9.10 & 4.16 & 1.85 & 0.926 \\
\hline 3 & $1 \mathrm{~N}$ & 90 & 42.67 & 2.89 & 3.98 & 4.00 & 10.19 & 4.25 & 3.89 & 0.865 \\
\hline 4 & $2 \mathrm{~N}$ & 30 & 54.44 & 2.10 & 4.03 & 3.22 & 8.22 & 4.31 & 2.33 & 0.983 \\
\hline 5 & $2 \mathrm{~N}$ & 60 & 46.14 & 1.94 & 3.86 & 2.92 & 7.95 & 4.07 & 2.19 & 0.887 \\
\hline 6 & $2 \mathrm{~N}$ & 90 & 39.63 & 2.46 & 3.55 & 2.87 & 8.01 & 4.19 & 1.63 & 0.785 \\
\hline 7 & $3 \mathrm{~N}$ & 30 & 66.14 & 1.49 & 3.96 & 4.36 & 6.95 & 3.88 & 4.97 & 1.131 \\
\hline 8 & $3 \mathrm{~N}$ & 60 & 66.01 & 1.61 & 3.94 & 5.05 & 6.78 & 4.05 & 4.75 & 1.125 \\
\hline 9 & $3 \mathrm{~N}$ & 90 & 60.95 & 1.49 & 3.60 & 4.72 & 5.42 & 4.09 & 3.83 & 1.021 \\
\hline 10 & $4 \mathrm{~N}$ & 30 & 50.35 & 1.55 & 4.04 & 4.48 & 2.17 & 4.04 & 0.42 & 0.873 \\
\hline 11 & $4 N$ & 60 & 53.37 & 1.52 & 3.93 & 4.60 & 2.21 & 4.00 & 0.41 & 0.935 \\
\hline 12 & $4 \mathrm{~N}$ & 90 & 47.06 & 1.46 & 3.63 & 4.62 & 1.48 & 4.17 & 0.30 & 0.806 \\
\hline 13 & $5 \mathrm{~N}$ & 30 & 63.42 & 1.49 & 3.82 & 2.54 & 7.39 & 3.91 & 4.57 & 1.095 \\
\hline 14 & $5 \mathrm{~N}$ & 60 & 63.31 & 1.49 & 3.81 & 2.28 & 6.80 & 3.93 & 2.98 & 1.095 \\
\hline 15 & $5 \mathrm{~N}$ & 90 & 62.16 & 1.36 & 3.79 & 2.18 & 6.75 & 3.95 & 3.50 & 1.036 \\
\hline 16 & $6 \mathrm{~N}$ & 30 & 63.30 & 1.61 & 3.68 & 6.15 & 0.36 & 3.88 & 0.44 & 1.036 \\
\hline 17 & $6 N$ & 60 & 64.96 & 1.56 & 3.94 & 8.14 & 0.86 & 3.95 & 0.85 & 1.101 \\
\hline 18 & $6 \mathrm{~N}$ & 90 & 60.16 & 1.42 & 3.54 & 8.79 & 0.24 & 4.08 & 0.55 & 0.978 \\
\hline 19 & $7 \mathrm{~N}$ & 30 & 58.62 & 1.47 & 3.42 & 2.69 & 0.64 & 3.90 & 0.15 & 0.952 \\
\hline 20 & $7 \mathrm{~N}$ & 60 & 62.49 & 1.53 & 3.67 & 2.58 & 0.19 & 4.17 & 0.17 & 1.006 \\
\hline 21 & $7 \mathrm{~N}$ & 90 & 58.23 & 1.40 & 3.44 & 2.50 & 0.05 & 4.09 & 0.10 & 0.935 \\
\hline 22 & $8 \mathrm{~N}$ & 30 & 61.73 & 1.46 & 3.61 & 2.65 & 0.06 & 3.92 & 0.11 & 0.969 \\
\hline 23 & $8 \mathrm{~N}$ & 60 & 59.73 & 1.44 & 3.50 & 2.73 & 0.19 & 3.81 & 0.24 & 0.960 \\
\hline 24 & $8 \mathrm{~N}$ & 90 & 55.50 & 1.40 & 3.29 & 2.44 & 0.04 & 4.14 & 0.16 & 0.873 \\
\hline 25 & $\mathrm{CN}$ & 30 & 61.98 & 1.44 & 3.63 & 2.51 & 0.07 & 3.93 & 0.26 & 1.006 \\
\hline 26 & $\mathrm{CN}$ & 60 & 66.61 & 1.47 & 3.83 & 2.70 & 0.43 & 3.93 & 0.54 & 1.068 \\
\hline 27 & $\mathrm{CN}$ & 90 & 59.07 & 1.40 & 3.37 & 2.56 & 0.05 & 4.13 & 0.31 & 0.935 \\
\hline
\end{tabular}




\section{RESULTS}

\section{Composition of Discs}

Data from oxide analyses of discs are in Table 4. Samples and exposure conditions are summarized in a notation used in this and other tables. For example, "02N" means the specimen was exposed to solution 2 and was made with mixing water containing no salt. " $S$ " indicates salt in the mixing water. "C" indicates control specimens, not exposed to solutions. Sometimes this notation is followed by another number, which indicates the time of exposure. For example, "08S60" means the specimen was made with salt in the mixing water, exposed to solution 8 for 60 days.

Data in Table 4 have been corrected by reference to $\mathrm{SiO}_{2}$ values, as described previously. Both the $\mathrm{SiO}_{2}$ and the $\mathrm{Fe}_{2} \mathrm{O}_{3}$ correction procedures revealed essentially the same patterns of chemical changes in the discs. The $\mathrm{SiO}_{2}$-based correction appeared to be a little more conservative in its description of effects. Data plotted in the figures will be based on them, although general trends do not differ with the correction used. Results of the primary bulk analysis of the discs along with the corrected values obtained with the $\mathrm{Fe}_{2} \mathrm{O}_{3}$-based corrections are in Appendix $\mathrm{C}$.

Table 5 summarizes the phases that were detected by X-ray diffraction (XRD) in the pastes after 14, 30, and 60 days exposure to brines. XRD data were not available for samples after 90-day exposure, due to inadvertent ignition of the specimens before XRD analyses were performed. In Table 5, the symbol $(\downarrow)$ for data from analyses after 30-day exposure indicates a decreased amount of this phase compared to the amount indicated by the 14-day analysis of the same sample. In addition to the phases described in Table 5, all samples have perceptible amounts of dicalcium silicate $\left(\mathrm{C}_{2} \mathrm{~S}\right)$ and tricalcium silicate $\left(\mathrm{C}_{3} \mathrm{~S}\right)$, representing unhydrated cement; and calcium silicate hydrate (CSH). Amounts of these phases remained fairly constant from 14 through 60-days exposure.

\section{Calcium Phases}

The most conspicuous brine-induced changes in the paste samples, detectable by elemental analysis, were in $\mathrm{CaO}$ levels. Large amounts of $\mathrm{CaO}$ were lost from specimens exposed to solutions highly concentrated in $\mathrm{Mg}$ ion (solutions 1 \& 2). This effect is illustrated in Figures 1 and 2 . The 


\begin{tabular}{|c|c|c|c|}
\hline Sample & 14 Days & 30 Days & 60 Days \\
\hline $\begin{array}{l}\text { Salt } \\
\text { Control } \\
\end{array}$ & $\mathrm{CH}, \mathrm{NaCl}, \mathrm{CCA}$ & $\mathrm{CH}, \mathrm{NaCl}, \mathrm{CCA}$ & $\mathrm{CH}, \mathrm{NaCl}, \mathrm{CCA}$ \\
\hline $01 \mathrm{~S}$ & $\mathrm{CH}$, Gypsum, $\mathrm{NaCl}, \mathrm{CCA}$ & $\begin{array}{l}\mathrm{CH} \downarrow \text {, Gypsum, } \mathrm{NaCl} \text {, } \\
\mathrm{CCA}\end{array}$ & Gypsum, $\mathrm{NaCl}, \mathrm{CCA}$ \\
\hline $02 S$ & $\mathrm{CH}, \mathrm{C}_{4} \mathrm{AF}, \mathrm{NaCl}, \mathrm{CCA}$ & $\mathrm{CH} \downarrow, \mathrm{NaCl}, \mathrm{CCA}$ & $\mathrm{NaCl}, \mathrm{CCA}$ \\
\hline $03 S$ & $\mathrm{CH}, \mathrm{NaCl}, \mathrm{CCA}$ & $\mathrm{CH}, \mathrm{NaCl}, \mathrm{CCA}$ & $\mathrm{CH}, \mathrm{NaCl}, \mathrm{CCA}, \mathrm{C}_{4} \mathrm{AF}$ \\
\hline $04 S$ & $\mathrm{CH}$, Ettringite & $\mathrm{CH} \downarrow$, Ettringite & $\mathrm{CH}$, Ettringite \\
\hline $05 \mathrm{~S}$ & $\mathrm{CH}, \mathrm{NaCl}$ & $\mathrm{CH}, \mathrm{NaCl}, \mathrm{CCA}$ & $\mathrm{CH}, \mathrm{NaCl}, \mathrm{CCA}, \mathrm{C}_{4} \mathrm{AF}$ \\
\hline $06 \mathrm{~S}$ & $\mathrm{CH}$, Gypsum & CH, Ettringite, Gypsum & $\begin{array}{l}\mathrm{CH} \text {, Ettringite, Gypsum, } \\
\mathrm{C}_{4} \mathrm{AF}\end{array}$ \\
\hline $07 \mathrm{~S}$ & $\mathrm{CH}$ & $\mathrm{CH}$ & $\mathrm{CH}$, Ettringite \\
\hline $08 \mathrm{~S}$ & $\mathrm{CH}$, Ettringite & $\mathrm{CH}, \mathrm{C}_{4} \mathrm{AF}$ & $\mathrm{CH}$ \\
\hline $\begin{array}{l}\text { No Salt } \\
\text { Control }\end{array}$ & $\mathrm{CH}$, Ettringite & $\mathrm{CH}$, Ettringite & $\mathrm{CH}$, Ettringite \\
\hline $01 \mathrm{~N}$ & CH, Ettringite, Gypsum & $\mathrm{CH} \downarrow$ & Ettringite, $\mathrm{CCA}$ \\
\hline $02 \mathrm{~N}$ & $\mathrm{CH}$, Ettringite, $\mathrm{CCA}$ & $\mathrm{CH} \downarrow, \mathrm{CCA}$ & Ettringite, CCA \\
\hline $03 \mathrm{~N}$ & $\mathrm{CH}, \mathrm{NaCl}$, Ettringite & $\mathrm{CH}, \mathrm{NaCl}$, Ettringite & $\mathrm{CH}, \mathrm{NaCl}$, Ettringite \\
\hline $04 \mathrm{~N}$ & $\mathrm{CH}$, Ettringite & $\mathrm{CH} \downarrow$, Ettringite & $\mathrm{CH}$, Ettringite \\
\hline $05 \mathrm{~N}$ & $\mathrm{CH}, \mathrm{NaCl}$ & $\mathrm{CH}, \mathrm{NaCl}$ & $\mathrm{CH}, \mathrm{NaCl}$, Ettringite \\
\hline $06 \mathrm{~N}$ & CH, Ettringite, Gypsum & $\mathrm{CH}$, Ettringite, Gypsum & $\mathrm{CH}$, Ettringite, Gypsum \\
\hline $07 \mathrm{~N}$ & $\mathrm{CH}$, Ettringite, $\mathrm{C}_{4} \mathrm{AF}$ & $\mathrm{CH}$, Ettringite, $\mathrm{C}_{4} \mathrm{AF}$ & $\mathrm{CH}$, Ettringite, $\mathrm{C}_{4} \mathrm{AF}$ \\
\hline $08 \mathrm{~N}$ & $\mathrm{CH}$, Ettringite & $\mathrm{CH}$, Ettringite & $\mathrm{CH}$, Ettringite \\
\hline \multicolumn{4}{|c|}{$\begin{array}{l}\text { In addition all samples have perceptible amounts of } \mathrm{C}_{2} \\
\text { indicates a decreasing amount of this phase compared } \mathrm{t} \\
\text { sample. } \\
\mathrm{CH}=\text { calcium hydroxide } \\
\mathrm{CCA}=\text { tetracalcium aluminate dichloride-10-hydrate } \\
\mathrm{C}_{4} \mathrm{AF}=\text { tetracalcium aluminoferrite } \\
\mathrm{C}_{2} \mathrm{~S}=\text { dicalcium silicate } \\
\mathrm{C}_{3} \mathrm{~S}=\text { tricalcium silicate } \\
\mathrm{CSH}=\text { calcium silicate hydrate } \\
\text { Ettringite = 6-calcium aluminate trisulfate-32-hydrate }\end{array}$} \\
\hline
\end{tabular}




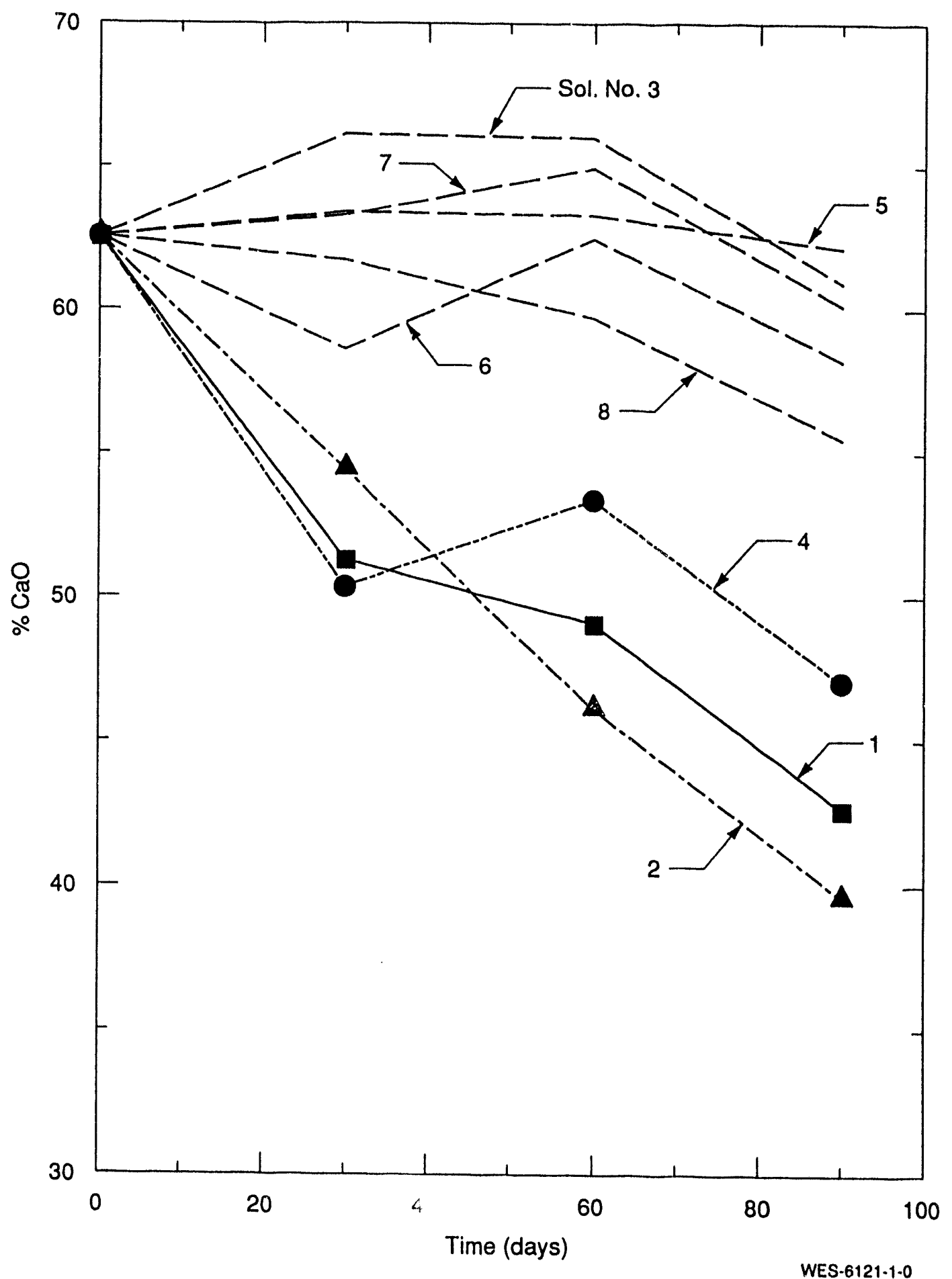

Figure 1. Percentage of $\mathrm{CaO}$ remaining in non-salt paste specimens. 




Figure 2. Percentage of $\mathrm{CaO}$ remaining in salt paste specimens. 
loss rate appears to be relatively linear, particularly in the case of solution 2 , and continuous through 90 days. Linear regression analysis of these data are presented in Table 6. Loss rates ranged from 0.21 to $0.28 \%$ per day. The presence of salt in the mixing water did not appear to exacerbate the $\mathrm{CaO}$-loss rate, although this cannot be concluded definitively without more replication, which is underway.

Table 6. Loss Rates of $\mathrm{CaO}$ Estimated from Linear Regression

\begin{tabular}{cccc}
\hline $\begin{array}{c}\text { Exposure } \\
\text { Condition }\end{array}$ & $\begin{array}{c}\text { Salt/ } \\
\text { Non-salt }\end{array}$ & $\begin{array}{c}\text { Loss Rate } \\
\text { (\% per day) }\end{array}$ & $\begin{array}{c}\text { 90\% Confidence } \\
\text { Interval on Rate }\end{array}$ \\
\hline 1 & $\mathrm{~N}$ & 0.21 & 0.12 \\
2 & $\mathrm{~N}$ & 0.27 & 0.03 \\
4 & $\mathrm{~N}$ & 0.14 & 0.19 \\
8 & $\mathrm{~N}$ & 0.08 & 0.05 \\
1 & $\mathrm{~S}$ & 0.21 & 0.11 \\
2 & $\mathrm{~S}$ & 0.28 & 0.09 \\
4 & $\mathrm{~S}$ & 0.14 & 0.20 \\
8 & $\mathrm{~S}$ & 0.08 & 0.06 \\
\hline
\end{tabular}

The phase analysis indicated several changes in calcium phases that resulted from exposure to these two solutions. Calcium hydroxide decreased with time and was no longer detectable after 60 days exposure to these solutions, both in salt and non-salt pastes. Levels of CSH appear to be constant with time. Some calcium chloroaluminate, calcium sulfoaluminate, and calcium sulfate were detected in pastes, but their presence appeared to depend on the concentrations of sulfate and chloride ions in the solutions and did not appear to be related to magnesium levels. Therefore, these will be discussed below with sulfate and chloride compounds.

Detectable, but smaller amounts of $\mathrm{CaO}$ were lost from specimens exposed to the solution with a moderate $\mathrm{Mg}$ concentration (soln. 4), as illustrated in Figure 1. These data fit a linear model poorly. The $\mathrm{CaO}$ loss under this condition was considerable between 0 and 30 days exposure. Losses after 30 days were minor. Phase analysis indicated that $\mathrm{CH}$ was depleted between 14 and 30 days, but then persisted past 60 days.

Very small amounts of $\mathrm{CaO}$ were lost when specimens were exposed to deionized water. Loss rates were $0.08 \%$ per day (Table 6 ). At the level of detection allowed by this experiment, there was no $\mathrm{CaO}$ lost as a result of exposure to any of the other solutions. 
There was some evidence that the $\mathrm{CaO}$-loss effect in high-magnesium ion solution was influenced by the sulfate concentration of the solutions. As illustrated in Figures 1 and 2, specimens exposed to solution 1 (high $\mathrm{Mg}$ and $\mathrm{SO}_{4}$ ) lost less $\mathrm{CaO}$ at later ages than did specimens exposed to solution 2 (high $\mathrm{Mg}$, low $\mathrm{SO}_{4}$ ). This difference was small relative to the experimental error estimated for single observations, but the nearly exact duplication of the pattern in both the salt and non-salt pastes may be significant.

\section{Magnesium Phases}

Patterns of magnesium accumulation in specimens are illustrated in Figures 3 and 4 . Increases in $\mathrm{MgO}$ content of the specimens occurred in exposure to the two solutions with high $\mathrm{Mg}$ ion concentrations (solutions 1 and 2). The effect was small but detectable (outside estimated experimental error) relative to controls at 30 days, and accumulation continued through the 90 -day test age. There was no detectable accumulation as a result of exposure to solution 4 , which contained moderate levels of $\mathrm{Mg}$ ion.

Particularly conspicuous was the accumulation of $\mathrm{MgO}$ in salt-containing specimens exposed to solution 2, which was high in magnesium and chloride, but low in sulfate. No magnesium phases were detected in any of the disks by XRD analysis.

\section{Silicon Phases}

Changes in $\mathrm{SiO}_{2}$ evidenced by elemental analysis are believed to be due solely to relative enrichment or depletion due to ingress or egress of other phases. When data were corrected by reference to $\mathrm{Fe}_{2} \mathrm{O}_{3}$, all $\mathrm{SiO}_{2}$ values fell within the experimental error defined by controls (see Appendix $\mathrm{B}$ for these data). This conclusion was also supported by the data from analyses of posttest solutions, presented later.

Silicon phases were detectable by XRD only as hydrated or unhydrated calcium silicates in the pastes. Levels of these did not change perceptibly during the experiment. 


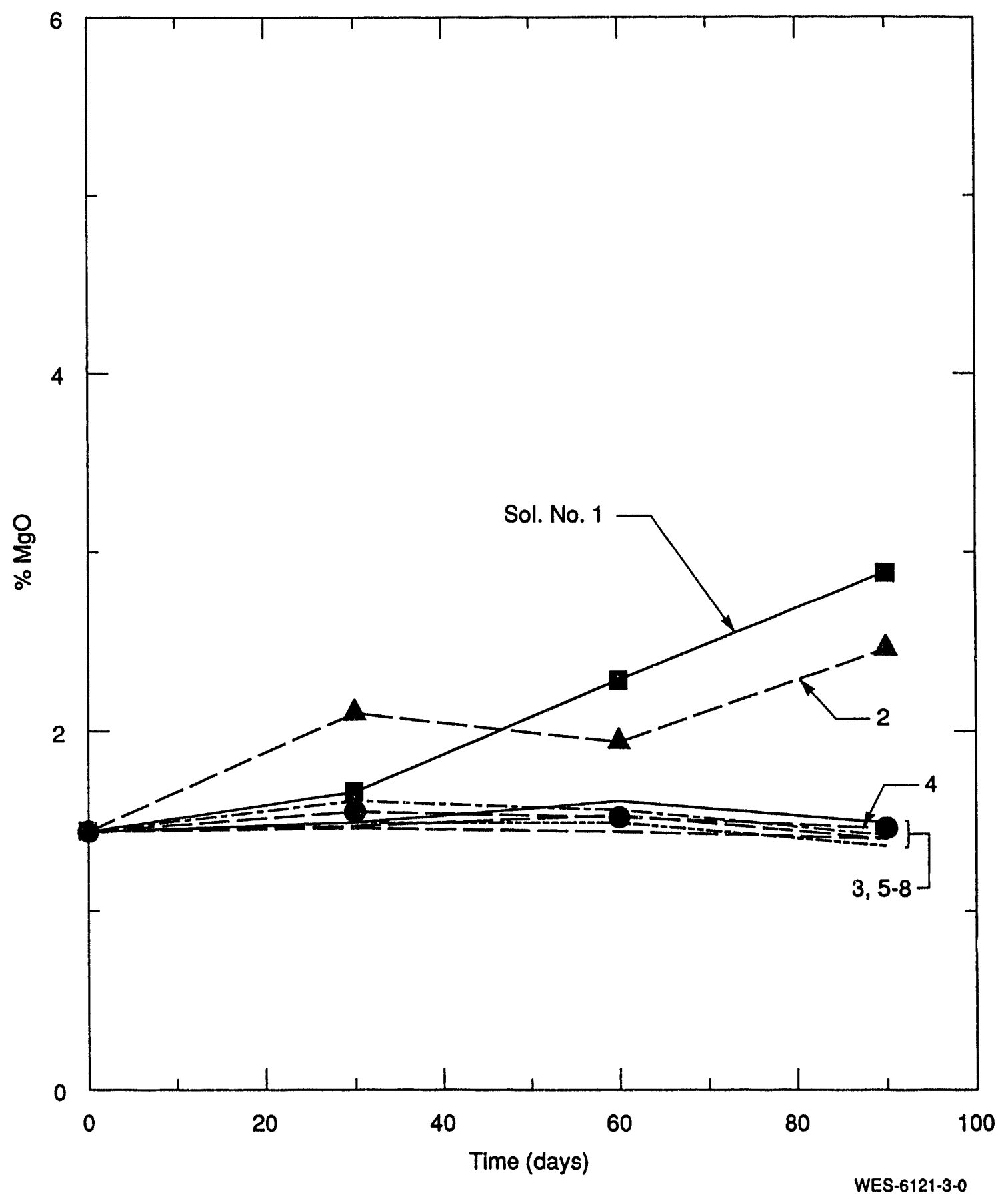

Figure 3. Percentage of $\mathrm{MgO}$ accumulated in non-salt specimens vs. exposure time. 


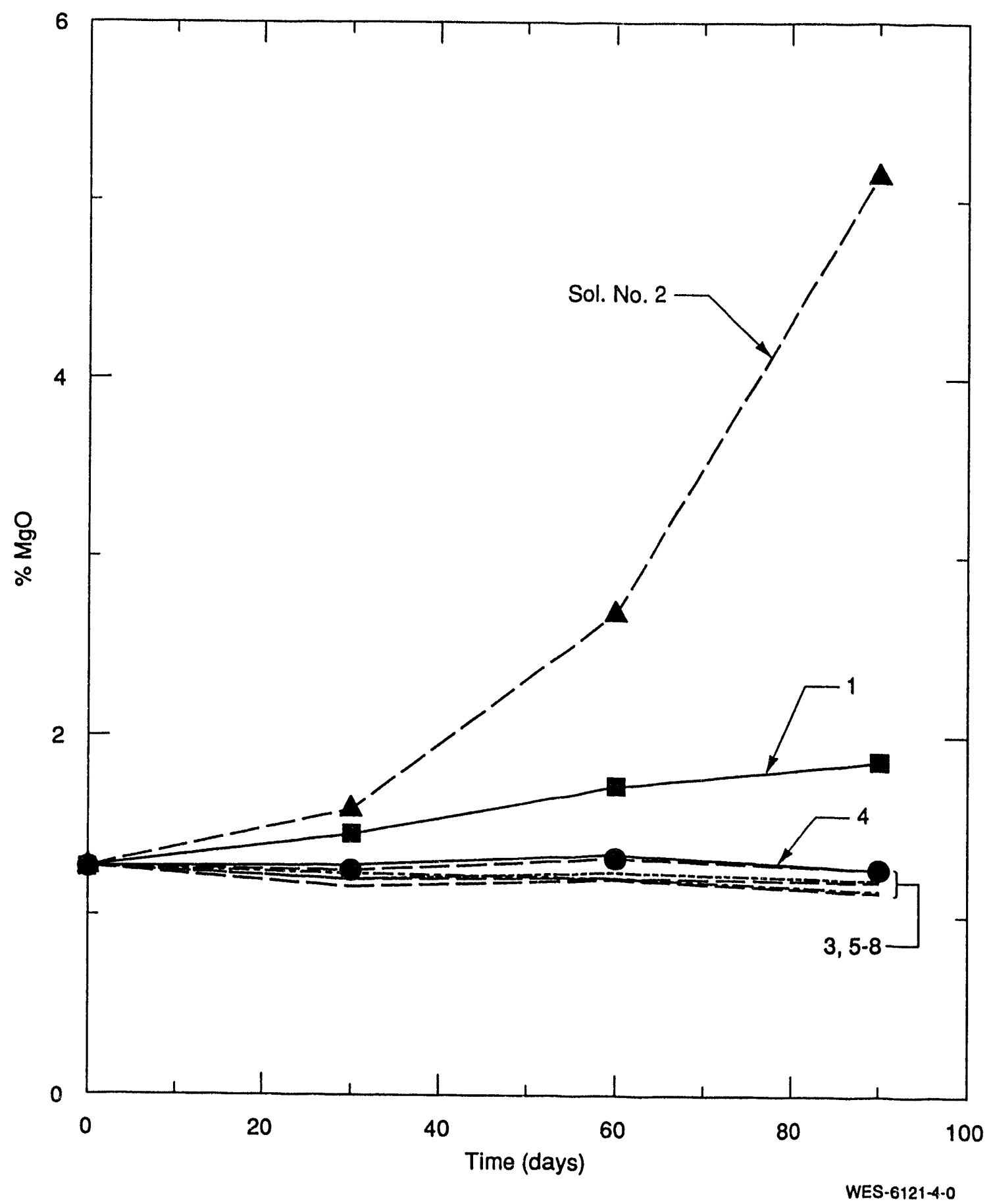

Figure 4. Percentage of $\mathrm{MgO}$ accumulated in salt pastes vs. exposure time. 


\section{Aluminum Phases}

The aluminum content of the cement was low for a portland cement, so formation of major quantities of aluminum-based phases was not expected. Elemental analysis showed no changes in paste concentrations of $\mathrm{Al}_{2} \mathrm{O}_{3}$ as a result of exposure to any of the solutions. Results of XRD analysis indicated that the aluminum was active in formation of calcium sulfoaluminate and calcium chloroaluminate. These appeared to be controlled by the concentrations of chlorides and sulfates in solution, and therefore, will be discussed below.

\section{Iron Phases}

There was no evidence, from either XRF or XRD analyses, that iron played any active role in the reaction between hydrated cement paste and exposure solutions. Tetracalcium aluminoferrite $\left(\mathrm{C}_{4} \mathrm{AF}\right)$, known to be a persistent phase in portland cement pastes, was detected after 60 days exposure of both non-salt and salt specimens to all solutions except for high-magnesium ion solutions. Although its presence was not always noted in XRD patterns, it does not come and go at random. Its presence is easily masked by other phases in complex assemblages.

\section{Sulfur Phases}

Sulfate ion appeared to be relatively mobile and reactive in this system. Concentrations appeared to be stable with time, reaching approximate equilibrium by 30 days. Figure 5 illustrates comparative accumulations among conditions at 90 days. Sulfate accumulations were high in specimens exposed to high or moderate sulfate ion concentrations in solution (solutions 1, 3, 4, and 6). Concentrations were particularly high in specimens exposed to solution 6, which was characterized by low chloride, high sulfate ion concentrations. Within these patterns, sulfate contents of non-salt specimens were always higher than those of salted specimens.

Gypsum and calcium sulfoaluminate (CSA) were the principal sulfate-containing compounds formed, as determined by XRD. In salt-containing specimens, CSA formed only when exposure was to solutions with low or moderate levels of chloride ion. In high-chloride high-sulfate ion solutions, 


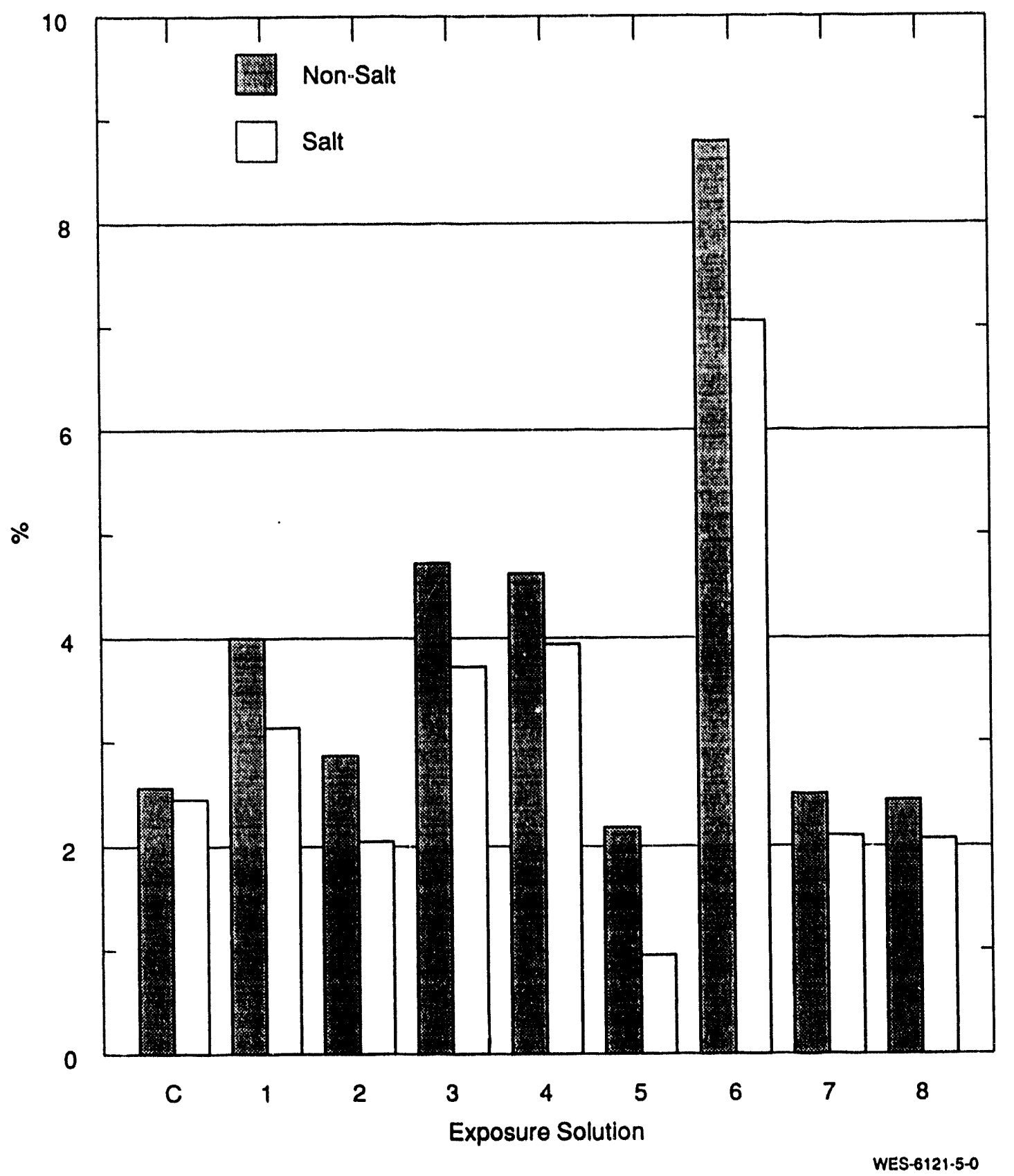

Figure 5. Accumulation of sulfate in cement pastes after 90 days in solutions. 
gypsum was the principal sulfate-bearing phase. In non-salt specimens, CSA was the principal sulfate-bearing phase. Gypsum formed from exposure to solution 6 (low chloride, high sulfate ion).

\section{Chlorine Phases}

Chloride ion also appeared to be relatively mobile and reactive. Concentrations were essentially stable by 30 days. Figure 6 illustrates 90 -day patterns of $\mathrm{Cl}$-ion concentrations.

In salt-containing specimens, $\mathrm{Cl}$-ion concentrations were high initially and stayed at similarly high levels when exposure was to high-Cl-ion solutions. Principal compounds identified by XRD were $\mathrm{NaCl}$ and calcium chloroaluminate (CCA). When exposed to low- $\mathrm{Cl}$-ion solutions, concentrations of chloride in the specimens decreased to very low values, and these compounds ceased to be detectable by XRD analysis.

In non-salt specimens, $\mathrm{Cl}$-ion concentrations were very low initially but approached levels comparable to the salt-containing specimens when the $\mathrm{Cl}$ ion concentration in the solutions was high. Somewhat less accumulation occurred in exposure to moderate chloride levels (solution 4). Except in exposure to solution 2, which was characterized by low sulfate concentrations, the principal $\mathrm{Cl}$ containing phase detected by XRD was $\mathrm{NaCl}$. No CCA was observed except in discs stored in solution 2 .

\section{Sodium Phases}

$\mathrm{Na}_{2} \mathrm{O}$ largely followed the pattern exhibited by chloride, except that where magnesium concentrations were high, $\mathrm{Na}_{2} \mathrm{O}$ concentrations were somewhat lower. This generally reflects the composition of the brines. Brines with high magnesium concentrations contained less $\mathrm{Na}$ ion than brines with low $\mathrm{Mg}$ ion concentrations. This inconsistency in sodium concentration among solutions was necessary to maintain charge balance in the solutions. One exception to this pattern appears in a comparison of specimens made with salt exposed to solutions 3 and 5 . Sodium levels in specimens exposed to solution 3 remain at about $5.5 \%$, while those in specimens exposed to solution 5 drop to about $2.5 \%$. The major difference in these solutions is that solution 3 contains high levels of sulfate. 


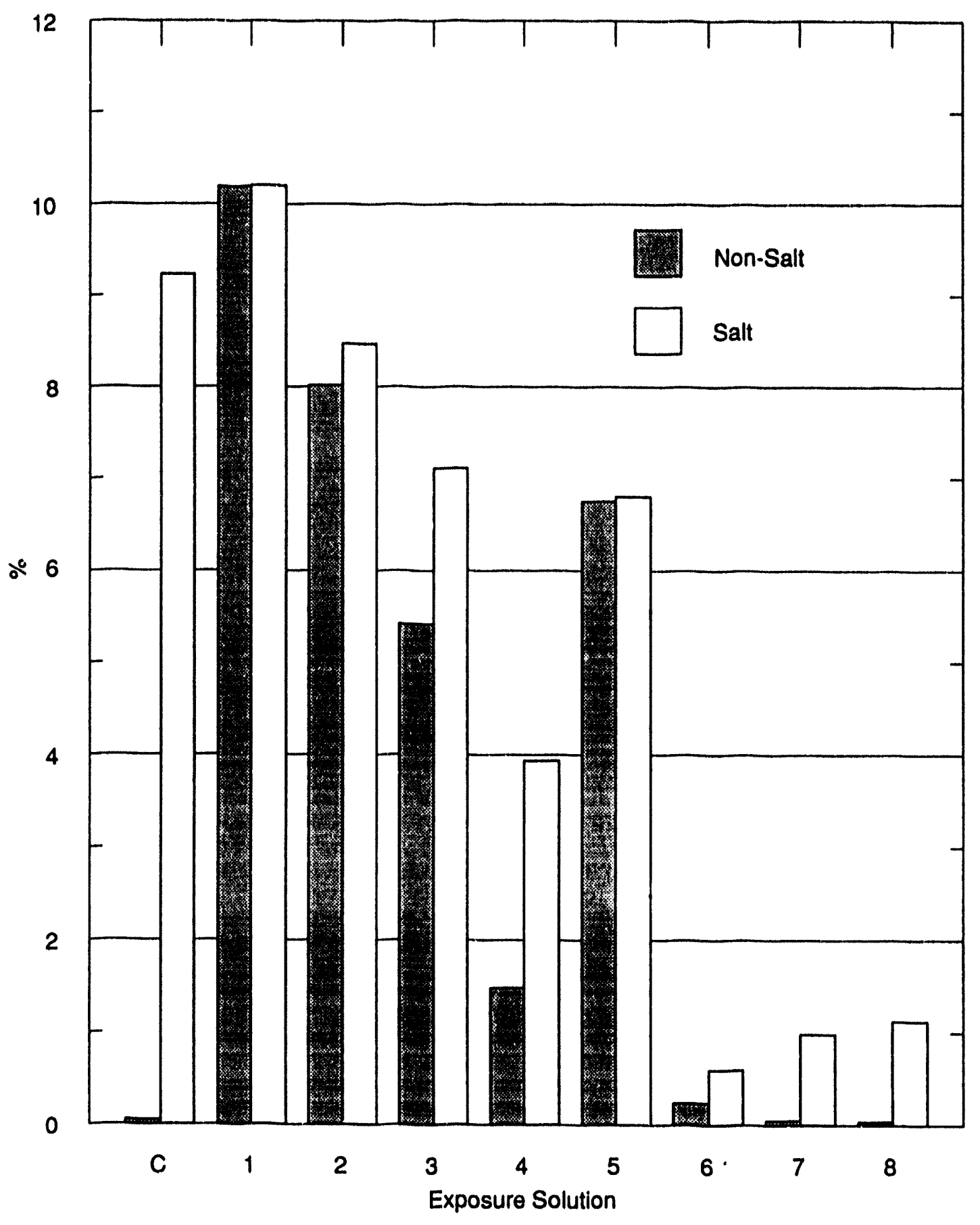

WES-6121-6-0

Figure 6. Total chloride in cement pastes after 90 days in solutions. 
In general, sodium levels do not change much with time over the 30 to 90 day interval represented in these experiments. This suggests that whether or not salt was added to the cement paste, the sodium probably reaches equilibrium in the system by about 30 days.

\section{Phase Composition of Precipitates}

Precipitates from the surfaces of four discs with the largest amount of surface accumulation were examined by XRD after 60 days in solution (first four entries, Table 7). All precipitates were analyzed after 90 days (Table 7). The relative amount of each phase was estimated from peak heights in diffraction patterns. Peak height, of course, does not indicate abundance directly, and we did not perform quantitative XRD analyses.

Working definitions of the abundance terms from Table 7 are as follows:

Major: $>30 \%$ of total sample

Minor: $<30 \%$ and $>5 \%$ of total sample, and

Trace: $<5 \%$ of total sample.

The percentages given are approximations from experience with XRD data, and were not calculated. These terms indicate relative amounts of the principal phases that crystallized on disc surfaces during exposure to solutions, and do not indicate total amount of precipitate that formed. Removal of these precipitates for analyses was difficult because the pastes had softened.

The amount of material precipitated on disc surfaces depended on the concentration of magnesium ion in solution. Specimens exposed to solutions 1, 2, and 4, which were either high or moderate in magnesium ion concentration, were coated with substantial amounts of precipitate. Precipitates on specimens exposed to solutions with high concentrations of chloride or sulfate ion or both, but low magnesium ion, were light. There was no perceptible precipitate on specimens exposed to solutions 7 and 8 (lime water and deionized water, respectively). Figures 7 and 8 show precipitates on two specimens immediately after removal from solution. The precipitate shown in Figure 7 is typical of exposure to solutions high in $\mathrm{Mg}$ and $\mathrm{SO}_{4}$ ions. Figure 8 illustrates typical precipitates formed after exposure to solutions high in $\mathrm{Mg}$, but low in $\mathrm{SO}_{4}$ ions. Descriptions of all precipitates are in Appendix B. 


\begin{tabular}{|c|c|c|c|c|c|c|}
\hline \multirow[b]{2}{*}{ Sample } & \multicolumn{6}{|c|}{ Phase } \\
\hline & $\begin{array}{c}\mathrm{CaSO}_{4} \cdot 2 \mathrm{H}_{2} \mathrm{O} \\
\text { Gypsum }\end{array}$ & $\begin{array}{c}\mathrm{Mg}(\mathrm{OH})_{2} \\
\text { Brucite }\end{array}$ & $\begin{array}{l}\mathrm{NaCl} \\
\text { Halite }\end{array}$ & $\begin{array}{l}\mathrm{CaCO}_{3} \\
\text { Calcite }\end{array}$ & $\begin{array}{l}\mathrm{C}_{6} \mathrm{AS}_{3} \mathrm{H}_{32} \\
\text { Ettringite }\end{array}$ & $\begin{array}{c}\mathrm{Ca}(\mathrm{OH})_{2} \\
\text { Portlandite }\end{array}$ \\
\hline $01 S 60$ & Major & Minor & Minor & & & \\
\hline $02 S 60$ & & Major & Minor & Minor & & \\
\hline $04 S 60$ & & Major & Minor & Minor & & \\
\hline $01 N 60$ & Major & Minor & Minor & & & \\
\hline 01590 & Major & Major & & & & \\
\hline 02590 & & Major & & & & \\
\hline 03590 & Major & & & & & \\
\hline 04590 & & Major & & Trace & & \\
\hline $05 S 90$ & & & & Trace & & Major \\
\hline $06 \$ 90$ & Major & & & & & \\
\hline $07 \$ 90$ & & & & Minor & & Major \\
\hline $08 \$ 90$ & & & & Minor & Trace & Major \\
\hline 01 N90 & Major & Major & Minor & & & \\
\hline $02 N 90$ & & Major & & & & \\
\hline 03N90 & Major & & Trace & & & \\
\hline $04 N 90$ & & Major & & Trace & & \\
\hline 05N90 & & & Minor & Minor & & Major \\
\hline 06 N90 & Major & Minor & & & & \\
\hline 07N90 & & & & Trace & & Major \\
\hline $08 N 90$ & & & detectab & recipitate & & \\
\hline
\end{tabular}



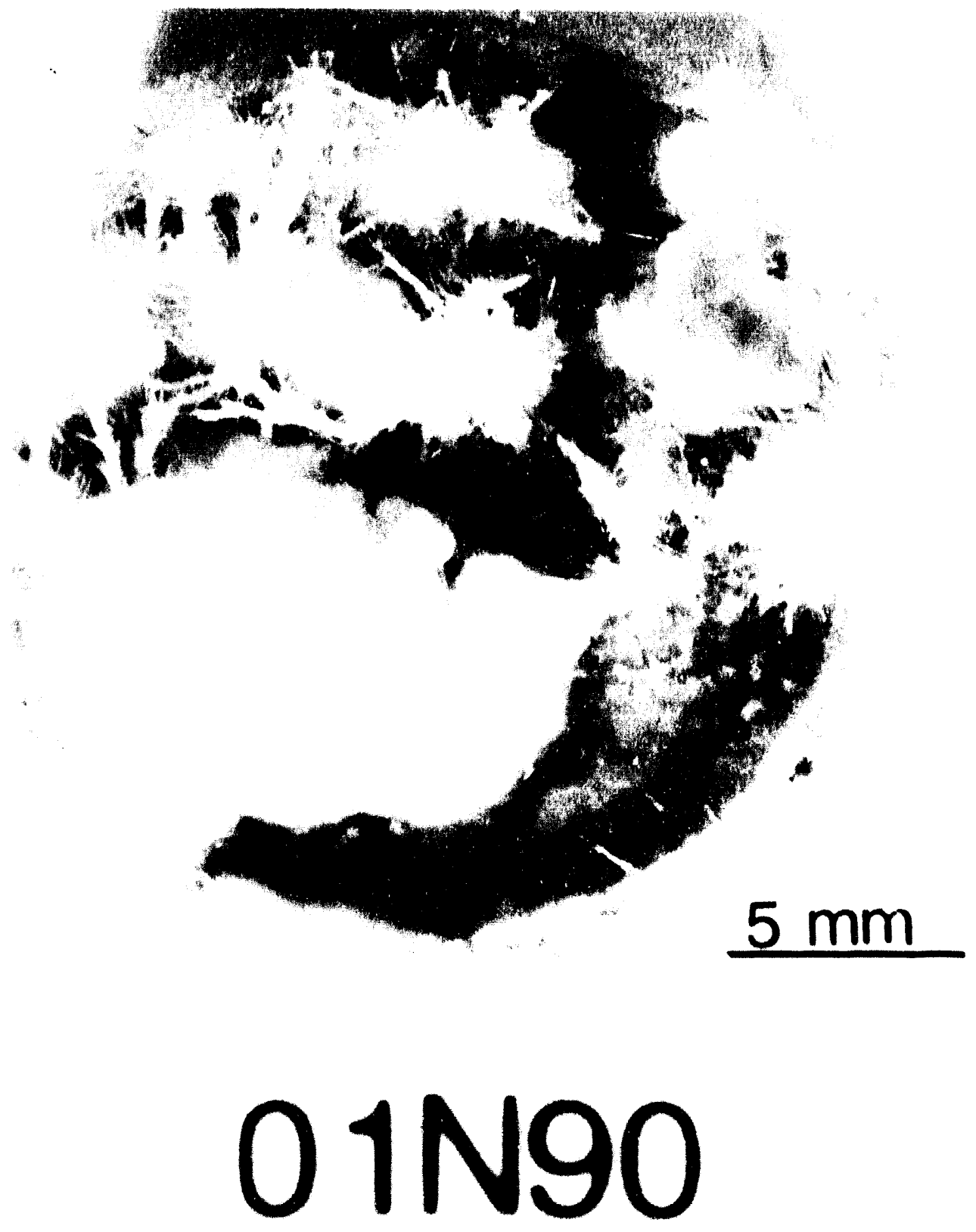

Figure 7. Photograph of specimen exposed to solution 1 for 90 days. 


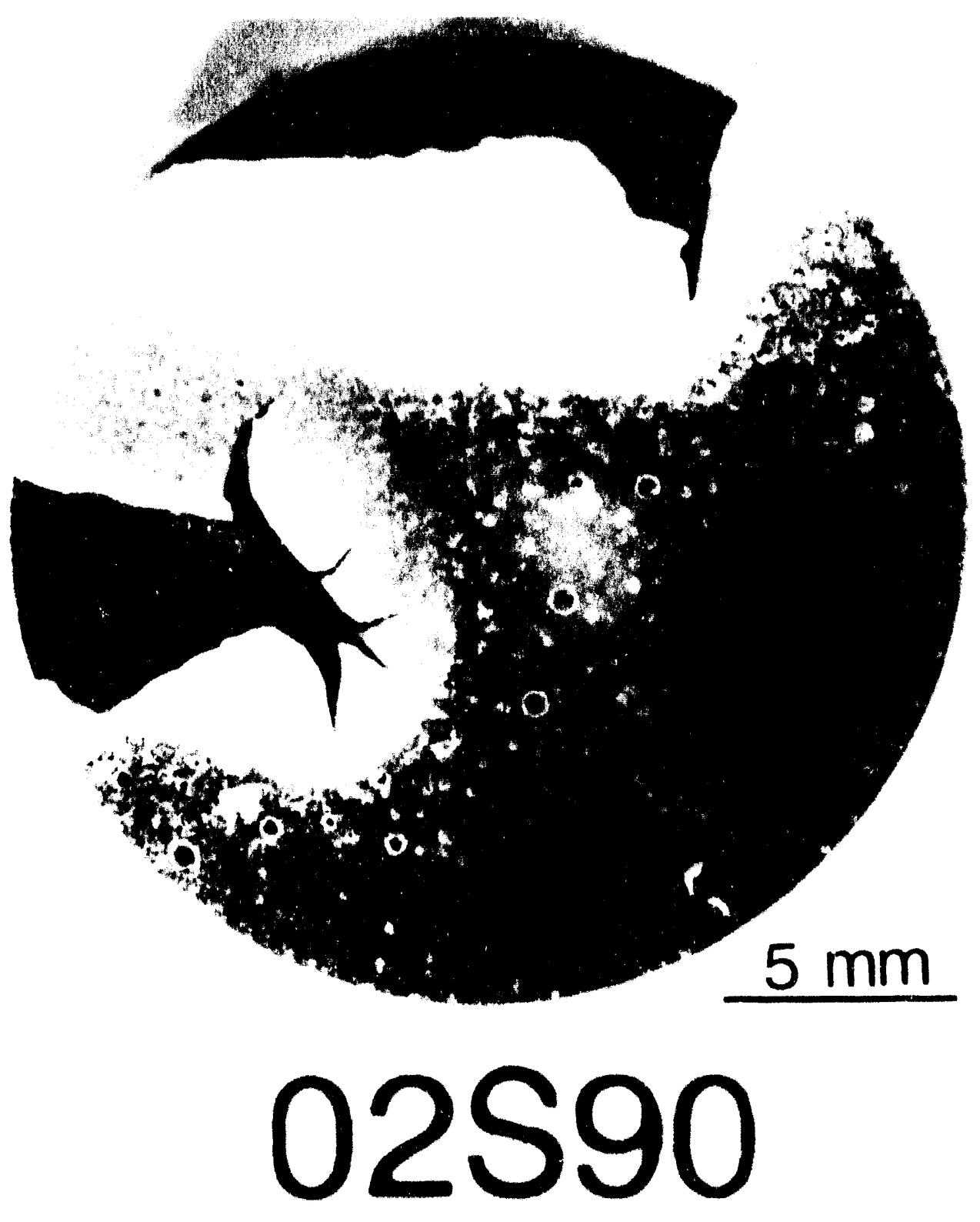

Figure 8. Photograph of specimen exposed to solution 2 for 90 days. 
The composition of surface precipitates appeared to depend on the ions in solution and their concentrations. With the exception of some halite, all were calcium-based phases. $\mathrm{CaSO}_{4} \cdot 2 \mathrm{H}_{2} \mathrm{O}$ (gypsum) was the major compound found in surface precipitates after exposure to high-sulfate solutions. $\mathrm{Mg}(\mathrm{OH})_{2}$ (brucite) was the major compound found when exposed to high- or moderatemagnesium solutions. Both brucite and gypsum formed when both sulfate and magnesium were in high concentration in solution. $\mathrm{Ca}(\mathrm{OH})_{2}$ (portlandite) was found on the surface of specimens exposed to solutions 5,7 , and 8 . These discs showed either minimal or virtually no surface accumulation, so the $\mathrm{CH}$ could have been derived from inadvertent removal of paste when surfaces were scraped.

\section{Composition of Liquid Phase}

Data from post-exposure analyses of solutions are summarized in Table 8. These analyses were conducted principally to determine whether or not cement constituents were being removed from the hydrated cement paste as a result of exposure to the solutions. Liquid-phase analysis is particularly useful in detecting leaching of relatively small quantities of calcium-bearing cement compounds since there is no background level of these in the liquid phase to complicate the analysis. In addition, these analyses were used to verify that magnesium ion levels in solution were not depleted, either by reaction with cement paste or precipitation on the specimen surface, to the point of inhibiting potential degradation reactions. In principle, analysis of the liquid phase, along with analysis of precipitated material and paste, should give the opportunity for mass-balance analysis among these three phases. In practice, this is difficult because of the analytical errors. The biggest problem is in estimating the fraction of material in the surface precipitate phases. It is difficult to remove all of this material without also taking some of the disks. And there is suspended material as well. Unlike using liquidphase analysis for detecting loss of cement compounds, using liquid phase analysis to estimate the concentrations of magnesium or other elements taken into the paste from solution is difficult. Because there are large quantities of these elements in the solutions, and because the ratio of liquid to specimen mass is large, relatively small changes in solution concentration occur, and these are close to the analytical error. 
Table 8. Solution Chemistry after Exposure to Specimens

\begin{tabular}{|c|c|c|c|c|c|c|c|c|c|}
\hline OBS & COND & AGE & $\mathrm{Ca}^{1}$ & $\mathrm{Mg}^{\prime}$ & $\mathrm{Fe}^{2}$ & $S^{1}$ & $\mathrm{Cl}^{1}$ & $\mathrm{Al}^{2}$ & $\mathrm{Na}^{1}$ \\
\hline 1 & $1 \mathrm{~N}$ & 0 & 0.00 & 17.13 & 868 & 2.32 & 53.91 & 464 & 14.26 \\
\hline 2 & $1 \mathrm{~N}$ & 14 & 0.54 & & & & & & \\
\hline 3 & $1 \mathrm{~N}$ & 30 & 0.41 & 17.56 & 37 & 1.16 & 51.43 & 561 & 12.61 \\
\hline 4 & $1 \mathrm{~N}$ & 60 & 0.94 & 14.55 & 68 & 1.55 & 52.28 & 555 & 13.41 \\
\hline 5 & $1 \mathrm{~N}$ & 90 & 0.85 & 13.79 & 25 & 0.90 & 51.95 & 472 & 13.60 \\
\hline 6 & $2 \mathrm{~N}$ & 0 & 0.01 & 12.69 & 1500 & 0.55 & 52.54 & 370 & 8.56 \\
\hline 7 & $2 \mathrm{~N}$ & 14 & 0.86 & & & & & & \\
\hline 8 & $2 \mathrm{~N}$ & 30 & 1.26 & 14.97 & 709 & 0.56 & 51.21 & 656 & 10.74 \\
\hline 9 & $2 \mathrm{~N}$ & 60 & 1.84 & 14.60 & 572 & 0.74 & 50.96 & 502 & 9.74 \\
\hline 10 & $2 \mathrm{~N}$ & 90 & 2.05 & 14.00 & 135 & 0.80 & 52.34 & 474 & 10.89 \\
\hline 11 & $3 \mathrm{~N}$ & 0 & 0.00 & 2.30 & 52 & 2.39 & 65.47 & 796 & 43.65 \\
\hline 12 & $3 \mathrm{~N}$ & 14 & 0.43 & &. &. & 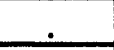 & . & 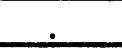 \\
\hline 13 & $3 \mathrm{~N}$ & 30 & 0.26 & 4.49 & 65 & 1.87 & 61.01 & 117 & 33.00 \\
\hline 14 & $3 \mathrm{~N}$ & 60 & 1.10 & 9.95 & 60 & 2.12 & 62.10 & 482 & 39.10 \\
\hline 15 & $3 \mathrm{~N}$ & 90 & 0.10 & 0.38 & 30 & 2.14 & 61.36 & 266 & 33.72 \\
\hline 16 & $4 N$ & 0 & 0.00 & 3.20 & 556 & 0.99 & 9.52 & 365 & 2.86 \\
\hline 17 & $4 \mathrm{~N}$ & 14 & 1.69 &. & . &. & - & $\therefore$ & - \\
\hline 18 & $4 \mathrm{~N}$ & 30 & 3.16 & 0.30 & 228 & 0.37 & 7.70 & 199 & 0.68 \\
\hline 19 & $4 \mathrm{~N}$ & 60 & 4.06 & 0.09 & 130 & 0.37 & 7.00 & 218 & 0.00 \\
\hline 20 & $4 \mathrm{~N}$ & 90 & 1.71 & 0.91 & 58 & 0.59 & 8.73 & 307 & 1.75 \\
\hline 21 & $5 \mathrm{~N}$ & 0 & 0.00 & 0.53 & 42 & 0.88 & 66.10 & 377 & 36.13 \\
\hline 22 & $5 \mathrm{~N}$ & 14 & 0.37 & & . &. & 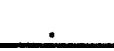 &. & - \\
\hline 23 & $5 \mathrm{~N}$ & 30 & 0.40 & 12.17 & 47 & 0.78 & 63.09 & 802 & 29.27 \\
\hline 24 & $5 \mathrm{~N}$ & 60 & 0.64 & 12.16 & 54 & 0.79 & 62.78 & 559 & 30.37 \\
\hline 25 & $5 \mathrm{~N}$ & 90 & 0.14 & 0.48 & 45 & 0.85 & 63.22 & 331 & 33.17 \\
\hline 26 & $6 \mathrm{~N}$ & 0 & 0.01 & 1.10 & 52 & 5.85 & 2.30 & 664 & 4.15 \\
\hline 27 & $6 \mathrm{~N}$ & 14 & 0.47 & $\dot{-}$ & . & - & $\dot{-}$ & $\therefore$ & - \\
\hline 28 & $6 \mathrm{~N}$ & 30 & 0.31 & 3.02 & 82 & 3.95 & 2.00 & 425 & 3.86 \\
\hline 29 & $6 \mathrm{~N}$ & 60 & 1.04 & 3.65 & 67 & 3.94 & 1.86 & 418 & 3.76 \\
\hline 30 & $6 \mathrm{~N}$ & 90 & 0.28 & 0.73 & 48 & 3.29 & 6.52 & 289 & 3.74 \\
\hline 31 & $7 N$ & 0 & 0.09 & 0.63 & 78 & 0.91 & 0.01 & 814 & 0.29 \\
\hline 32 & $7 \mathrm{~N}$ & 14 & 1.06 & &. & - & . & $\cdot$ & \\
\hline 33 & $7 \mathrm{~N}$ & 30 & 1.28 & 0.28 & 81 & 0.61 & 0.01 & 303 & 0.00 \\
\hline 34 & $7 \mathrm{~N}$ & 60 & 1.22 & 0.62 & 70 & 0.75 & 0.02 & 465 & 0.22 \\
\hline 35 & $7 \mathrm{~N}$ & 90 & 0.42 & 0.50 & 87 & 0.44 & 4.19 & 313 & 0.82 \\
\hline 36 & $8 \mathrm{~N}$ & 0 & 0.00 & 0.34 & 45 & 0.79 & 0.02 & 506 & 0.10 \\
\hline 37 & $8 \mathrm{~N}$ & 14 & 0.78 & & & & & . & \\
\hline 38 & $8 \mathrm{~N}$ & 30 & 0.84 & 0.81 & 80 & 0.75 & 0.03 & 553 & 0.76 \\
\hline 39 & $8 \mathrm{~N}$ & 60 & 0.79 & 0.82 & 68 & 0.90 & 0.01 & 752 & 0.63 \\
\hline 40 & $8 \mathrm{~N}$ & 90 & 0.41 & 0.00 & 92 & 0.18 & 4.12 & 895 & 0.14 \\
\hline \multicolumn{10}{|c|}{ (Continued) } \\
\hline
\end{tabular}


Table 8. (Concluded)

\begin{tabular}{|c|c|c|c|c|c|c|c|c|c|}
\hline OBS & COND & AGE & $\mathrm{Ca}$ & $\mathrm{Mg}$ & $\mathrm{Fe}$ & $S$ & $\mathrm{Cl}$ & $\mathrm{Al}$ & $\mathrm{Na}$ \\
\hline 1 & $1 S$ & 0 & 0.00 & 17.13 & 868 & 2.32 & 53.91 & 464 & 14.26 \\
\hline 2 & $1 \mathrm{~S}$ & 14 & 0.35 & & & & & $\dot{ }$ & $\cdot$ \\
\hline 3 & 15 & 30 & 0.42 & 15.50 & 59 & 0.98 & 52.17 & 354 & 13.37 \\
\hline 4 & is & 60 & 1.60 & 17.70 & 148 & 1.58 & 52.22 & 442 & 13.02 \\
\hline 5 & 15 & 90 & 0.84 & 10.75 & 69 & 0.77 & 51.53 & 395 & 11.48 \\
\hline 6 & $2 S$ & 0 & 0.01 & 12.69 & 1500 & 0.55 & 52.54 & 370 & 8.56 \\
\hline 7 & $2 S$ & 14 & 0.91 & & & & & $\dot{\square}$ & \\
\hline 8 & $2 S$ & 30 & 1.24 & 16.92 & 639 & 0.57 & 52.07 & 367 & 11.57 \\
\hline 9 & $2 S$ & 60 & 2.00 & 21.04 & 810 & 0.64 & 52.26 & 415 & 11.81 \\
\hline 10 & $2 S$ & 90 & 2.63 & 12.42 & 157 & 0.64 & 53.35 & 709 & 11.63 \\
\hline 11 & $3 S$ & 0 & 0.00 & 2.30 & 52 & 2.39 & 65.47 & 796 & 43.65 \\
\hline 12 & $3 S$ & 14 & 0.44 & $\dot{-}$ & . & $\dot{ }$ &. &. & 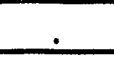 \\
\hline 13 & $3 S$ & 30 & 0.33 & 4.74 & 58 & 1.68 & 60.81 & 113 & 31.67 \\
\hline 14 & $3 S$ & 60 & 0.37 & 9.80 & 62 & 1.92 & 62.18 & 430 & 36.70 \\
\hline 15 & $3 S$ & 90 & 0.10 & 2.56 & 32 & 2.11 & 64.47 & 718 & 41.00 \\
\hline 16 & $4 S$ & 0 & 0.00 & 3.20 & 556 & 0.99 & 9.52 & 365 & 2.86 \\
\hline 17 & $4 S$ & 14 & 1.98 & & & &. & $\dot{-}$ &. \\
\hline 18 & $4 S$ & 30 & 2.74 & 1.99 & 139 & 0.54 & 10.45 & 570 & 3.56 \\
\hline 19 & $4 S$ & 60 & 3.54 & 0.07 & 225 & 0.70 & 10.80 & 677 & 3.57 \\
\hline 20 & $4 S$ & 90 & 2.18 & 0.48 & 96 & 0.44 & 12.67 & 239 & 2.26 \\
\hline 21 & $5 S$ & 0 & 0.00 & 0.53 & 42 & 0.88 & 66.10 & 377 & 36.13 \\
\hline 22 & $5 S$ & 14 & 0.40 & & 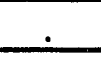 & . &. &. &. \\
\hline 23 & $5 S$ & 30 & 0.38 & 7.60 & 108 & 0.59 & 62.49 & 363 & 30.11 \\
\hline 24 & $5 S$ & 60 & 0.57 & 10.13 & 64 & 0.85 & 64.40 & 661 & 35.15 \\
\hline 25 & $5 \mathrm{~S}$ & 90 & 0.15 & 2.23 & 40 & 0.69 & 65.17 & 781 & 36.54 \\
\hline 26 & $6 S$ & 0 & 0.01 & 1.10 & 52 & 5.85 & 2.30 & 664 & 4.15 \\
\hline 27 & $6 S$ & 14 & 0.64 & & & 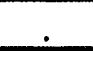 & 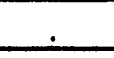 & 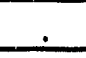 & 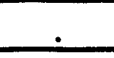 \\
\hline 28 & $6 S$ & 30 & 0.65 & 8.86 & 65 & 3.69 & 4.71 & 348 & 4.91 \\
\hline 29 & $6 S$ & 60 & 1.83 & 8.47 & 61 & 3.61 & 4.32 & 385 & 4.83 \\
\hline 30 & $6 S$ & 90 & 0.30 & 1.13 & 58 & 2.67 & 9.37 & 490 & 5.22 \\
\hline 31 & $7 \mathrm{~S}$ & 0 & 0.09 & 0.63 & 78 & 0.91 & 0.01 & 814 & 0.29 \\
\hline 32 & $7 \mathrm{~S}$ & 14 & 1.18 & $\dot{-}$ & - & $\therefore$ & $\circ$ & . &. \\
\hline 33 & $7 S$ & 30 & 1.26 & 0.71 & 119 & 0.49 & 2.35 & 410 & 1.45 \\
\hline 34 & 75 & 60 & 1.54 & 0.65 & 106 & 0.47 & 2.24 & 353 & 1.35 \\
\hline 35 & $7 S$ & 90 & 0.43 & 0.00 & 84 & 0.19 & 5.60 & 896 & 0.24 \\
\hline 36 & $8 S$ & 0 & 0.00 & 0.34 & 45 & 0.79 & 0.02 & 506 & 0.10 \\
\hline 37 & $8 S$ & 14 & . & . & - & . &. & . & . \\
\hline 38 & $8 S$ & 30 & 0.75 & 0.00 & 92 & 0.39 & 2.05 & 262 & 0.00 \\
\hline 39 & $8 S$ & 60 & 0.75 & 0.68 & 75 & 0.65 & 1.94 & 477 & 1.38 \\
\hline 40 & $8 S$ & 90 & 0.50 & 0.30 & 47 & 0.39 & 5.18 & & 0.65 \\
\hline
\end{tabular}


Calcium and chloride were the only ions that showed any measurable tendency to come out of the paste. $\mathrm{Ca}$ ion levels increased significantly in solution 2 (high $\mathrm{Mg}$, low sulfate, high $\mathrm{Cl}$ ) and 4 (moderate $\mathrm{Mg}$ ), but were only slightly elevated in solution 1 (high $\mathrm{Mg}$, high sulfate, high $\mathrm{Cl}$ ). Chloride ion levels were elevated when salt-containing specimens were exposed to solutions 6,7 , and 8. High chloride ion levels at $\mathbf{9 0}$ days are due to the addition of $\mathrm{HCl}$ to acidify the solutions.

There was a pattern for some solutions to show higher calcium and magnesium levels at 14,30 , and 60 days than at 90 days. This is believed to be an artifact of the acid treatment at 90 days. Solutions that had not been acidified tended to be cloudy with suspended insoluble materials. It seems probable that during analysis, these phases settled onto the bottom window of the XRF sample container, thus getting preferential exposure to the incident $\mathrm{X}$-rays. This caused the suspended phases to be over-represented in the analysis up to 60 days. At 90 days, acidification caused dissolution of these phases before the post-test solutions were analyzed. Therefore, 90-day data probably more accurately represent the total concentration of dissolved and particulate $\mathrm{Mg}$ and $\mathrm{Ca}$ compounds.

$\mathrm{Mg}$ ion levels showed no evidence of serious depletion in the high-Mg solutions ( $1 \& 2)$, but there was measurable depletion in solution 4 by 90 days. This occurred in solutions containing both salt and non-salt specimens. 


\section{INTEGRATION OF RESULTS}

\section{Relationships Between $\mathrm{Ca}^{2+}$ Movement and Other lons in Solution}

The $\mathrm{Ca}$ loss detected by chemical analysis of discs exposed to high $\mathrm{Mg}$ concentrations corresponds with the disappearance of calcium hydroxide $(\mathrm{CH})$, as determined by XRD (Table 5). However, Ca loss continued through 90 days, whereas $\mathrm{CH}$ was no longer detectable by 60 days. This indicates that a substantial amount of $\mathrm{Ca}$ must have been lost from other phases in the hydrated pastes in addition to that lost from calcium hydroxide.

In Figures 1 and 2, loss rates for all low-Mg solutions group together at the top of each Figure. Loss rates are similar for solutions 1, 2, and 4, with high and moderate $\mathrm{Mg}$, at 30 days age. At later ages these curves diverge, with $\mathrm{Ca}$ loss from pastes appearing to continue at a faster rate in solutions with the highest $\mathrm{Mg}$ (curves 1 and 2, Figures 1 and 2). The rate of $\mathrm{Ca}$ loss also correlated with the concentration of $\mathrm{Mg}$ ion in the exposure solutions. If the early $\mathrm{Ca}$ losses are principally due to loss of $\mathrm{CH}$, then this part of the reaction mechanism. occurs whether the $\mathrm{Mg}$ concentration is moderate or high. There is an order of magnitude difference in the $\mathrm{Mg}$ concentration of the high-Mg solutions compared to the moderate-Mg solutions (Table 1).

Comparison of $\mathrm{Ca}$ lost with $\mathrm{Mg}$ gained by the specimens indicated that there was not a simple replacement of $\mathrm{Ca}$ by $\mathrm{Mg}$ in the pastes. The mechanism proposed earlier in this report indicates a Ca-to-Mg ratio of 1 in the first phase of the deterioration reaction (i.e., replacement of $\mathrm{CH}$ by $\mathrm{MH}$ ), and a ratio of less than 1 in the second phase (i.e., formation of $\mathrm{MSH}$ ). The changes in molar ratios of $\mathrm{Ca}$ to $\mathrm{Mg}$ in the paste at any time in the experiment relative to the controls were heavily skewed to values above one. $\mathrm{Mg}$ accumulation was not substantial until well after large amounts of Ca were lost from the paste. Figure 9 shows a high ratio of $\mathrm{Ca}$ loss relative to $\mathrm{Mg}$ gain at early ages. This ratio decreases with time, as $\mathbf{M g}$ gain increases. Although $\mathbf{M g}$ accumulation increased markedly by 90 days, molar ratios were still considerably above one.

There was no strong relationship between $\mathrm{Ca}$ movement from the hydrated paste and abundance of any component of the exposure solution other than $\mathrm{Mg}$. However, there was a weak pattern involving sulfate ion concentration. Comparing the two high-Mg solutions (1 and 2), the one low in 


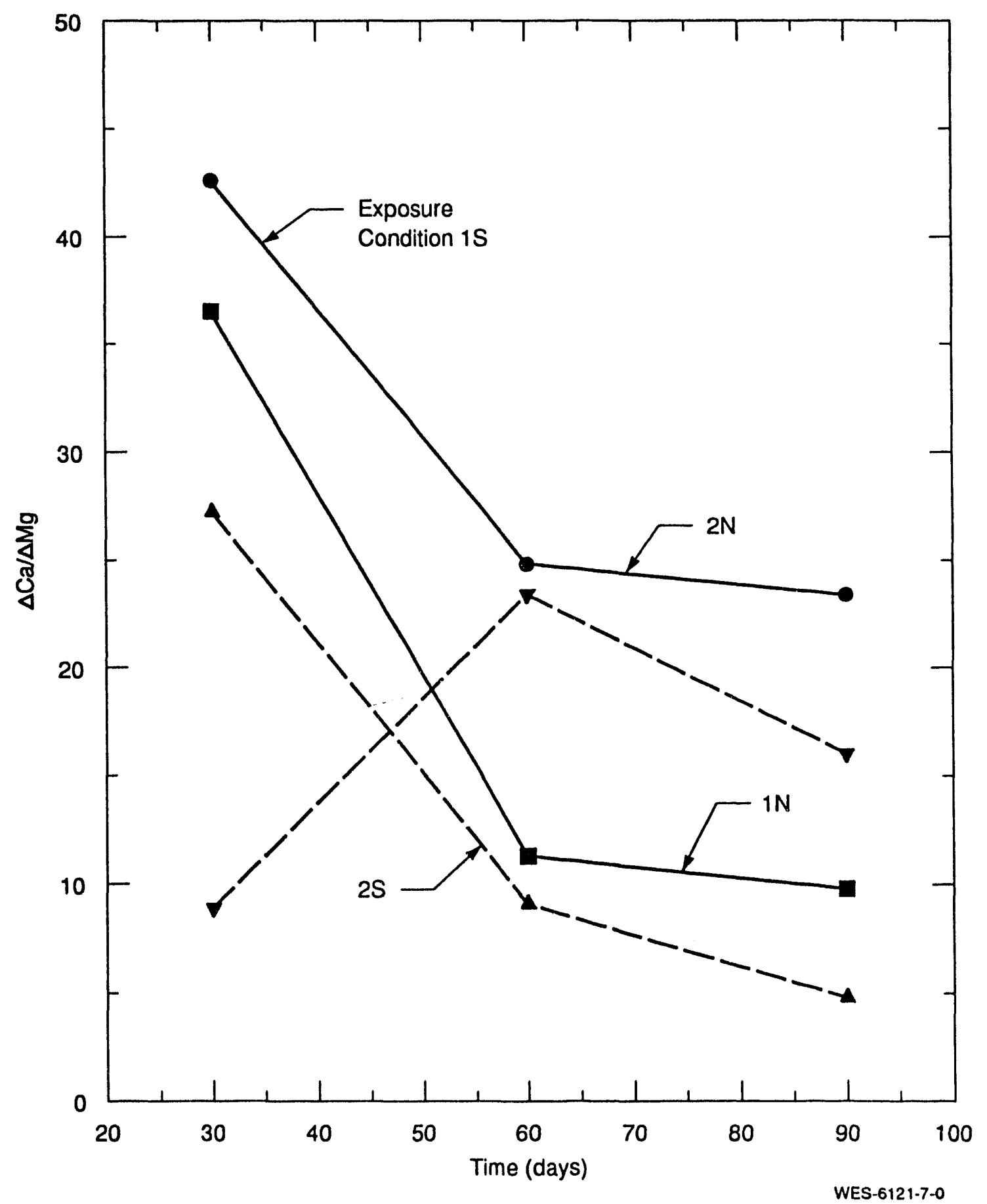

Figure 9. Molar ratio of $\mathrm{Ca}$ loss to $\mathrm{Mg}$ gain vs. exposure time. 
sulfate (solution 2) appeared to be associated with a greater loss rate of $\mathrm{Ca}$ than was the solution high in sulfate (1). The difference was small, given the levels of experimental error associated with this work, but the pattern duplicated almost identically in both the salted and non-salted specimens.

There is no step in the published proposed mechanism of $\mathbf{M g}$ attack suggesting that the presence of $\mathrm{SO}_{4}$ should diminish the effect of $\mathrm{Mg}$ ion on Ca loss. To the contrary, it was expected that, if there was an effect, it would be to enhance Ca loss through the opening of the paste microstructure that sometimes occurs when calcium sulfoaluminate forms. The apparent reduced $\mathrm{Ca}$ loss in high $\mathrm{SO}_{4}$ conditions could be attributable to the formation of gypsum from reaction of sulfate and calcium ions. Gypsum is a slightly soluble salt. Gypsum was detectable in the pastes exposed to high $\mathrm{SO}_{4}$ environment of solution 1 .

Levels of $\mathrm{Cl}$ and $\mathrm{SO}_{4}$ in the exposure solution strongly affected the form taken by the released Ca. For example, the $\mathrm{Ca}$ lost during exposure to solution 1 , which was highly concentrated in $\mathbf{M g}$, $\mathrm{Cl}$, and $\mathrm{SO}_{4}$, contributed to gypsum that crystallized on the surface of the specimen. Ca levels in solution did not increase much, evidently because most of the $\mathrm{Ca}$ stopped in this surface layer. In contrast, after exposure to solution 2, which differed from solution 1 in that $\mathrm{SO}_{4}$ was low, the $\mathrm{Ca}$ concentration of the solution increased, and no Ca phases appeared on the surface of the specimen.

\section{Relationships Between $\mathrm{Cl}^{\circ}$ and $\mathrm{SO}_{4}{ }^{*}$}

Although $\mathrm{Cl}$ and $\mathrm{SO}_{4}$ ions did not appear to have much affect on $\mathrm{Ca}$ loss from the hydrated cement system, these ions apparently were mobile. They reacted to form phases in the cement paste. When $\mathrm{Cl}$ ion concentrations were high in solution and initially low in the paste, they moved into the paste and reached equilibrium levels by the earliest test age, 30 days. When the reverse was true, the $\mathrm{Cl}$ ions moved out of the paste, again reaching approximate equilibrium by 30 days. High $\mathrm{Cl}$-ion levels in the paste were associated with the formation of both halite and calcium chloroaluminate (CCA), but these compounds were not stable enough to hold the $\mathrm{Cl}$ there against the strong concentration gradient presented by low- $\mathrm{Cl}$ solutions.

As with $\mathrm{Cl}, \mathrm{SO}_{4}$ ions appeared to move readily into pastes when they were in high concentration in solution. When $\mathrm{Cl}$ concentrations in the pastes were low initially, i.e. non-salt specimens, the $\mathrm{SO}_{4}$ formed calcium sulfoaluminate. Subsequent ingress of $\mathrm{Cl}$ did not appear to affect 
this phase. When $\mathrm{Cl}$ concentrations in the pastes were high initially, i.e. salt specimens, calcium chloroaluminate formed and subsequent ingress of $\mathrm{SO}_{4}$ resulted in the formation of gypsum. Ettringite formed only if the $\mathrm{Cl}$ concentration in brine was low, so that all $\mathrm{Cl}$-bearing phases were leached out, allowing the sulfate to react with the aluminate phases. An example is seen in the salt specimens exposed to solution 6, which was highly concentrated in $\mathrm{SO}_{4}$, but low in $\mathrm{Cl}$ and $\mathrm{Mg}$. The $\mathrm{Cl}$ was leached out and $\mathrm{SO}_{4}$ was incorporated in the discs, forming first gypsum (by 14 days), then ettringite (by 30 days; Table 5). 


\section{DISCUSSION}

\section{Mechanism of Deterioration}

From previously published hypotheses of the mechanism of deterioration as discussed in the "Background" Chapter of this report, it was expected that Ca loss would be controlled by the action of $\mathrm{Mg}$ ion and that the replacement of $\mathrm{Ca}$ by $\mathrm{Mg}$ would be about 1:1 on a molar basis, at least initially. The results of this work support the hypothesis that the presence of $\mathbf{M g}$ in an exposure solution promotes $\mathrm{Ca}$ depletion from hydrated paste. However, the rate of accumulation of $\mathbf{M g}$ documented in this study does not indicate a simple one-for-one molar replacement, as would occur via the previously published mechanism.

A direct replacement of $\mathrm{Ca}$ by $\mathrm{Mg}$ may not be expected if the $\mathrm{MSH}$ is forming in large quantities and it has a different bonding relationship with $\mathrm{Si}$. There is some unpublished evidence to suggest that the $\mathrm{Mg}-\mathrm{Si}$ ratio in MSH is lower than the $\mathrm{Ca}-\mathrm{Si}$ ratio in $\mathrm{CSH}$. If this difference in ratios is real, and if large amounts of MSH had formed, then the apparent imbalance between $\mathrm{Mg}$ and $\mathrm{Ca}$ could be explained. However, there is no evidence in these data to indicate even the formation of MSH, although it is difficult to detect by the analytical methods used. Even if some MSH is forming, the ratios $\mathrm{Ca}$ lost to $\mathrm{Mg}$ gained in the pastes probably are too large to be explained by this difference in silicate bonding between CSH and MSH.

A notable amount of $\mathrm{Mg}(\mathrm{OH})_{2}$ accumulated on the surfaces of the specimens that lost much Ca. We do not have total chemical analyses of these precipitates, so it is not possible to look at Ca-Mg ratios that include this source of $\mathrm{Mg}$. However, the observed patterns suggest that $\mathrm{Mg}$ does not remove $\mathrm{Ca}$ at the site in the cement paste where the $\mathrm{Ca}$ exists. It may act more remotely, perhaps in a through-solution mechanism.

The $\mathrm{Ca}$ in the paste exists in two pools: in solution, and in solid phases such as CSH and $\mathrm{Ca}(\mathrm{OH})_{2}$. The balance is far in favor of the solid phases. These two pools of $\mathrm{Ca}$ are in equilibrium through the liquid phase, so $\mathrm{Ca}$ exchange occurs between them. Ca loss from both pools could be explained as follows. The $\mathrm{Ca}$ in solution could move to the surface of the specimen, react there with $\mathrm{Mg}$, and leave a $\mathrm{Mg}$ compound as $\mathrm{Ca}$ is released into the solution. Removal of the solubilized form of $\mathrm{Ca}$ causes more of the crystalline $\mathrm{Ca}$ compounds to go into solution, so the removal ultimately involves $\mathrm{Ca}$ from both pools. 
As $\mathrm{Ca}$ is depleted from the near-surface regions of the specimen, the paste structure becomes more open and the $\mathrm{pH}$ decreases. This allows $\mathrm{Mg}^{2+}$ to diffuse readily toward the interior of the sample establishing a new "front" for further removal of $\mathrm{Ca}$.

$$
\mathrm{Ca}(\mathrm{OH})_{2}[\text { solid }]-\mathrm{Ca}^{2+}+2 \mathrm{OH}^{1-}+\mathrm{Mg}^{2+}[\text { solution }] \sim \mathrm{Mg}(\mathrm{OH})_{2}+\mathrm{Ca}^{2+}
$$

This mechanism of reaction implies differences in the relative mobility of $\mathrm{Ca}^{2+}$ and $\mathrm{OH}^{-}$ions, compared to that of $\mathrm{Mg}^{2+}$ and $\mathrm{Cl}^{-}$ions. If the $\mathrm{Ca}$ and $\mathrm{OH}$ were more mobile, this would explain why they would move to the surface of the specimen and there react with $\mathbf{M g}$ and $\mathrm{Cl}$, rather than $\mathbf{M g}$ and $\mathrm{Cl}$ moving into the specimen and reacting in place on the $\mathrm{Ca}$ compounds. If mobilities were about equal, or if $\mathrm{Mg}$ and $\mathrm{Cl}$ were more mobile in the cement paste, then it would be expected that the reaction would occur in the paste rather than at the surface of the specimen.

Although there are other controlling factors, the rate of diffusion of an ion should be related in some way to the effective radius of that ion. Ions tend to react electrically with water molecules, increasing their effective radius in aqueous solutions over the actual ionic radius. The hydrated radii of $\mathrm{Cl}^{-}$and $\mathrm{OH}^{-}$ions are similar: $30 \mathrm{~nm}$ for the former and $35 \mathrm{~nm}$ for the latter. The hydrated radius of $\mathrm{Mg}^{2+}$, at $8 \mathrm{~nm}$, is somewhat larger than the hydrated radius of $\mathrm{Ca}^{2+}$, at $6 \mathrm{~nm}$, even though $\mathrm{Ca}$ is larger than $\mathrm{Mg}$. These relationships are consistent with the proposed hypothesis, but they probably represent a serious oversimplification. They require the assumption that cement paste is a highly porous medium to which conventional diffusion equations apply. Cement pastes are microporous at best, and many of the ions of interest here react with solid phases. Also, charges on solid-phase surfaces are likely to play an important role (Chatterji and Kawamura, 1992).

An unresolved question in this investigation is the lack of identity for the $\mathbf{M g}$ compounds formed by the $\mathrm{Mg}$ that does accumulate in the pastes. $\mathrm{MgO}$ levels as high as $3.5 \%$ above controls accumulated in at least one paste, but no detectable $\mathrm{Mg}$ compounds were identified by XRD. According to the hypothesized deterioration mechanism, it was expected that either MH or MSH would be seen. $\mathrm{MH}$ is readily identifiable by XRD. If very much were present, it would have been detected. The diffraction pattern for MSH, on the other hand, is poorly described. There is at least one citation that indicates that MSH forms considerably after CSH is destroyed (Bonen, 1992), so perhaps its absence here is reasonable. It is notable that the exposure condition that resulted in the greatest $\mathrm{Ca}$ loss, solution $2 \mathrm{~S}$, also resulted in the greatest $\mathrm{Mg}$ gain. 


\section{Durability Implications}

For the WIPP panel seals and other large concrete placements, the process of interest is the rate at which the concrete might lose structural integrity. Given that the strength-giving phases of cement-

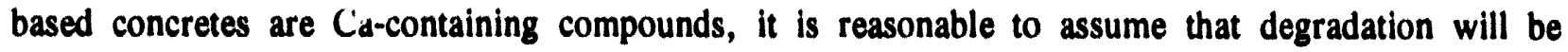
approximately proportional to the rate at which $\mathrm{Ca}$ is lost from the paste fraction of the concrete. There are other factors of this system that are important to long-term durability, as discussed below.

$\mathrm{Ca}$ is an essential component of several cementitious phases in concrete. $\mathrm{CSH}$ is generally considered to be the most abundant and most important. Either loss of this phase or replacement of it with MSH results in large strength loss of the paste. Calcium aluminate hydrates are important in determining setting behavior and early strength, but loss of these phases is not as critical for longterm strength.

Calcium hydroxide constitutes up to about $15 \%$ of hydrated cement paste (Lea, 1971). CH generally is more porous than CSH, and is thought to be more susceptible to chemical degradation processes than is CSH. Potentially more important, however, is the role of $\mathrm{CH}$ in bonding at the paste-aggregate interface. Most concretes have an interfacial zone of $\mathrm{CH}$, surrounding all aggregate particles and providing much of the bond between hydrated cement pastes and aggregates.

The strength of the paste-aggregate interface is very important in determining strength of concrete, because this zone provides the bond between cement paste and aggregates (Bentz et al., 1992). If this phase were preferentially removed, its loss could have implications for loss of concrete strength that exceed its compositional level in the paste. The present study did not explore this question, because the experimental matrix was designed to delineate chemical reactions between brines and cement phases, so there were no aggregates. Other parameters of mixture proportioning, especially water-cement ratio, also exert strong controls on pore structure and on the rate at which strongly ionic fluids are transmitted to and through concrete. Efforts to use rate of Ca loss to estimate deterioration in a real exposure scenario must deal with these complexities.

Understanding the seal system requires knowing how each component will react relative to each other component: not only strength gain and response to lithostatic load, but possible strength loss with time. If all concrete components of the seal system could be located where there is no brine, then acceptable service of an appropriately proportioned and placed concrete is certain. But the 
presence of brine brings the potential for chemical deterioration, and the possibility that a concrete may not maintain the properties measured at an early age.

Component materials and proportions can be selected to improve the chances of long-term durability if you know what is the most likely problem. Identifying the potential mechanisms of deterioration of concrete in WIPP brine is a necessary step in selecting component materials with enhanced chemical resistance. The strict performance requirements of a waste repository will demand that chemical properties and projected performance of a material are verified before its use. The results of this study also will be used in establishing a chemical test protocol for concrete to be used at the WIPP. 


\section{Approaches to Determining Rate of Deterioration}

Past work at WES on cement-based materials for use at the WIPP has indicated that magnesium-based deterioration of hydrated portland cement materials is likely where $\mathbf{M g}$-ion concentrations are high in the ground water. Although careful tailoring of the materials used as components of concrete can mitigate and possibly delay the deterioration (Wakeley et al., 1993), some degradation of structural integrity is likely over the long term, and its prevention is not guaranteed by conventional variations in materials. Therefore, it is essential to develop the capability to estimate the rate of loss of integrity under exposure conditions likely to be encountered at the WIPP.

Three approaches have merit: real-time exposures, accelerated-time exposures, and modeling based on estimates of deterioration of small volumes of material. These are discussed individually below.

The advantage of real-time exposure of relatively large-scale specimens to ground water is that it minimizes the number of assumptions that must be made about the system. There are several weaknesses. One is the extended time required to get enough deterioration to develop a reasonably quantitative evaluation. Exposure of 2 -in. mortar cubes required about a year to give measurable results, and then the deterioration involved only the first few millimetres in from the surface of the specimen. Another weakness is that results apply only to the specific materials and conditions represented in the test, which taken with the problem of testing time creates a cumbersome evaluation procedure. Still another problem exists in developing suitable evaluation criteria. Deterioration of large specimens immersed in brine is not homogeneous throughout the specimen, but develops as a slow-moving zone of deterioration from the outside. Measuring compressive strength then indicates an average integrity of the specimen and is not sensitive to zoning or other details of the deterioration process. Measuring some property such as fundamental frequency could be used to indicate rate of deterioration, but it is difficult to interpret the implications of such a test directly to engineering properties and field performance.

Accelerated-time testing such as exposure to higher temperature is an improvement on real-time testing, in that it can reduce the effect of cumbersome time-related problems. However, scaling results to real time is difficult unless there is some extended real-time data with which to calibrate the accelerated test method. 
Another approach is to measure real-time rate of deterioration on a specimen small enough that significant effects can be observed in a short time. These effects then can be extrapolated to a larger mass of concrete through a mathematical model. If the specimen is small enough, then changes at a specific time can be considered to be homogeneous throughout. Consequently, evaluation criteria are more easily interpreted. The negative side of this approach is that assumptions are required about the way deterioration spreads, beyond the small unit volume in direct contact with the solution to other unit volumes located farther from the surface. The simplest assumption is one in which deterioration on the surface is linearly extrapolated into the specimen. This probably results in the worst-case scenario, but may be too simple. It is possible that deterioration on the surface of the concrete will retard the rate of deterioration of subsurface material.

This third approach has another advantage. Modeling allows the convenient exploration of many conditions, such as brine flow scenarios and $\mathrm{Mg}$ concentration profiles, without the encumbrance of real-time testing. Given the relatively rapid rate of reactions observed in this study, a combination of real-time testing and modelling is recommended.

Subsequent work at WES will explore the microstructure of concrete specimens before and after brine exposure. Results of this work are being analyzed to determine whether the loss of $\mathrm{Ca}$ ions occurs through general mass loss, or if it causes localized opening of the pore structure. Deterioration had progressed only about $1 \mathrm{~mm}$ into samples exposed to high-magnesium brine for 15 months. This work will be reported during 1994, and should provide another tool to use in determining implications for long-term integrity of concrete seals. These early results indicate that deterioration is very slow even where brine supply is unlimited and a large surface area is exposed. 


\section{CONCLUSIONS}

Deterioration of portland cement pastes in brines containing high concentrations of $\mathbf{M g}, \mathbf{C l}$, and $\mathrm{SO}_{4}$ is due principally to the reaction between the $\mathrm{Mg}$ in solution and the $\mathrm{Ca}$ in the hydrated cement. Other salts are less important in the relatively low-aluminate system investigated. The results support the hypothesis of deterioration by $\mathrm{Ca}$ loss in the presence of $\mathbf{M g}$. Calcium hydroxide was shown to be the principal source of $\mathrm{Ca}$ ions removed by this reaction, accompanied by softening of the paste. This loss is not accompanied by deposition of $\mathrm{MH}$ in the cement paste. But, MH accumulated on surfaces and as a suspended phase. More Ca leaves the cement paste than can be accounted for by the CH. Yet some CSH persisted. We found no evidence for formation of MSH, thought previously to be the principal phase that forms during $\mathrm{Mg}$-related deterioration.

Accumulation of $\mathrm{Mg}$ in cement paste does not directly indicate deterioration. Consistently, far more $\mathrm{Ca}$ leaves than the amount of $\mathrm{Mg}$ that is added to the crystalline phase assemblage remaining as deteriorated cement paste. Because the strength of a concrete is attributed by Ca-bearing phases, $\mathrm{Ca}$ loss from the cementitious system should be a useful tool with which to investigate deterioration of candidate systems: knowing amount of $\mathrm{Ca}$ lost should permit calculation of loss of structural integrity. Determining which pools of $\mathrm{Ca}$ are most affected and how this relates to physical properties will provide an essential tool for establishing a standard chemical testing protocol for concretes to be used at the WIPP. 


\section{REFERENCES}

Bentz, D.P., P.E. Stutzman, and E.J. Garboczi. 1992. "Experimental and Simulation Studies of the Interfacial Zone in Concrete," Cement and Concrete Research. Vol. 22, no. 5, 891-902.

Biczok, I.D. 1972. Concrete Corrosion Concrete Protection. 8th ed. Budapest: Akademiai Kiado.

Bonen, D. 1992. "Composition and Appearance of Magnesium Silicate Hydrate and Its Relation to Deterioration of Cement-Based Materials," Journal of the American Ceramics Society. Vol. 75, no. 10, 2904-2906.

Bonen, D., and M.D. Cohen. 1992. "Magnesium Sulfate Attack on Portland Cement Paste - I. Microstructural Analysis," Cement and Concrete Research. Vol. 22, no. 1, 169-180.

Buck, A.D., K. Mather, and B. Mather. 1984. Cement Composition and Concrete Durability in Sea Water. Technical Report SL-84-21. Vicksburg, MS: U.S. Army Engineer Waterways Experiment Station.

Chatterji, S., and M. Kawamura. 1992. "Electrical Double Layer, Ion Transport and Reactions in Hardened Cement Paste," Cement and Concrete Research. Vol. 22, no. 5, 774-782.

Ftikos, C., and G. Parissakis. 1985. "The Combined Action of $\mathrm{Mg}^{2+}$ and $\mathrm{Cl}^{-}$Ions in Cement Pastes," Cement and Concrete Research. Vol. 15, no. 4, 593-599.

Gulick, C.W., and L.D. Wakeley. 1989. Reference Properties of Cement-Based Plugging and Sealing Materials for the Waste Isolation Pilot Plant (WIPP). Technical Report SL-89-17. Vicksburg, MS: U.S. Army Engineer Waterways Experiment Station.

Harmon, J.C., G. Wyld, and T.C. Yao. 1978. "X-Ray Fluorescence Analysis of Stainless Steels and Low Alloy Steels Using Secondary Targets and the EXACT Program," Advances in X-Ray Analysis, Proceedings of the Annual Conference on Applications of X-Ray Analysis, Denver, CO, August 1-4, 1978. New York, NY: Plenum Press. 325-335.

Helmy, I.M., A.A. Amer, H. El-Didamony, and A.M. Amin. 1991. "Chemical Attack on Hardened Pastes of Blended Cements. Part I: Attack of Chloride Ions," Zement-Kalk-Gipps. Edition B. Vol. 44, no. 1, 46-50.

Kevex Instruments. 1990. Kevex XRF Toolbox ${ }^{m}$ II Reference Manual. P/N 7180-5060 C. Valencia CA: Kevex Instruments. (Copy on file at the Nuclear Waste Management Library, Sandia National Laboratories, Albuquerque, NM.)

Krumhansl, J.L., K.M. Kimball, and C.L. Stein. 1991. Intergranular Fluid Compositions from the Waste Isolation Pilot Plant (WIPP), Southeastern New Mexico. SAND90-0584. Albuquerque, NM: Sandia National Laboratories.

Kuenning, W.H. 1966. "Resistance of Portland Cement Mortar to Chemical Attack - A Progress Report," Highway Research Record Number 113, Symposium on Effects of Aggressive Fluids on Concrete, 44th Annual Meeting, January 11-15, 1965. Washington, DC: Highway Research Board of the Division of Engineering and Industrial Research, National Academy of SciencesNational Research Council. 43-87. 
Lambert, S.J., E.J. Nowak, L.D. Wakeley, and T.S. Poole. 1992. "Interactions Between Concrete and Brine at the Waste Isolation Pilot Plant (WIPP) Site, New Mexico," Scientific Basis for Nuclear Waste Management, Annual Fall Meeting of the Materials Research Society, Boston, MA, December 2-6, 1991. Eds. F.P. Glasser, P.L. Pratt, T.O. Mason, J.F. Young, and G.J. McCarthy. SAND91-1421. Pittsburgh, PA: Materials Research Society. 111-116.

Lankard Materials Laboratory, Inc. 1991. Final Report No. I-2480-3 on Deterioration of the Waste Shaft Liner Concrete at the WIPP Site to Westinghouse Electric Corporation, Waste Isolation Pilot Plant, Carlsbad, New Mexico. Columbus, OH: Lankard Materials Laboratory, Inc. (Copy on file at the Nuclear Waste Management Library, Sandia National Laboratories, Albuquerque, NM.)

Lea, F.M. 1971. The Chemistry of Cement and Concrete. 3rd ed. New York, NY: Chemical Publishing Co.

Massazza, F. 1985. "Concrete Resistance to Seawater and Marine Environment," Il Cimento. Vol. 82, no. 1, 3-26.

Mather, B. 1966. "Effects of Seawater on Concrete," Highway Research Record No. 113. Symposium on Effects of Aggressive Fluids on Concrete, 44th Annual Meeting, January 11-15, 1965. Washington, DC: Highway Research Board of the Division of Engineering and Industrial Research, National Academy of Sciences-National Research Council. 33-42.

Oberste-Padtberg, R. 1985. "Degradation of Cements by Magnesium Brines," Proceedings of the Seventh International Conference on Cement Microscopy. Eds. J. Bayles, G.R. Gouda, and A. Nisperos. Duncanville, TX: International Cement Microscopy Association. 24-36.

Smith, D.K. 1990. Cementing. Richardson, TX: Society of Petroleum Engineers.

Smolczyk, H.G. [1968.] "Supplementary Paper III-31 Chemical Reactions of Strong ChlorideSolutions with Concrete," Proceedings of the Fifth International Symposium on the Chemistry of Cement, Tokyo, 1968. Part III, Properties of Cement Paste and Concrete (Volume III). The Cement Association of Japan. 274-280. (Copy on file at the Nuclear Waste Management Library, Sandia National Laboratories, Albuquerque, NM.)

Wakeley, L.D. 1990. "Grouts and Concretes for the Waste Pilot Project (WIPP)," Scientific Basis for Nuclear Waste Management XIII, Materials Research Society Symposium Proceedings, Boston, MA, November 27-30, 1989. Eds. V.M. Oversby and P.W. Brown. Pittsburgh, PA: Materials Research Society. Vol. 176, 45-51.

Wakeley, L.D., T.S. Poole, C.A. Weiss, [Jr.], and J.P. Burkes. [1992.] "Geochemical Stability of Cement-Based Composites in Magnesium Brines," [Proceedings of the Fourteenth International Conference on Cement Microscopy. Duncanville, TX: International Cement Microscopy Association. 333-342.] (Copy on file at the Nuclear Waste Management Library, Sandia National Laboratories, Albuquerque, NM.)

Wakeley, L.D., P.T. Harrington, and C.A. Weiss, Jr. 1993. Properties of Salt-Saturated Concrete and Grout after Six Years In Situ at the Waste Isolation Pilot Plant. SAND93-7019. Albuquerque, NM: Sandia National Laboratories. 
APPENDIX A: PROPORTIONS OF SALADO MASS CONCRETE, AND PROPERTIES OF CEMENT AND STANDARD BRINE 


\begin{tabular}{||l|c|}
\hline \multicolumn{2}{|c|}{ Table A-1. Mixture Proportions, Salado Mass Concrete } \\
\hline Mixture/Component & $\mathrm{lb} / \mathrm{yd}^{3}$ \\
\hline $\begin{array}{l}\text { Cement, Class H, sulfate-resistant oil } \\
\text { well cement }\end{array}$ & 190 \\
\hline Class F Fly Ash & 263 \\
\hline Fine Aggregate & 1,294 \\
\hline Coarse Aggregate & 1,658 \\
\hline Salt & 84 \\
\hline Chem Comp & 110 \\
\hline Na Citrate & 3.5 \\
\hline Air Detraining Agent & 5.6 \\
\hline Water & 246 \\
\hline
\end{tabular}

\begin{tabular}{|c|c|c|c|}
\hline \multicolumn{2}{|l|}{ Chemical Analysis } & \multicolumn{2}{|l|}{ Physical Properties } \\
\hline Property & Analysis (\%) & Property & Analysis \\
\hline $\begin{array}{l}\mathrm{SiO}_{2} \\
\mathrm{Al}_{2} \mathrm{O}_{3} \\
\mathrm{Fe}_{2} \mathrm{O}_{3} \\
\mathrm{CaO} \\
\mathrm{MgO} \\
\mathrm{SO}_{3} \\
\mathrm{Loss} \text { on Ignition } \\
\text { Insoluble Residue } \\
\mathrm{Na}_{2} \mathrm{O} \\
\mathrm{K}_{2} \mathrm{O} \\
\mathrm{TiO}_{2} \\
\mathrm{P}_{2} \mathrm{O}_{3} \\
\mathrm{C}_{3} \mathrm{~A} \\
\mathrm{C}_{3} \mathrm{~S} \\
\mathrm{C}_{2} \mathrm{~S} \\
\mathrm{C}_{4} \mathrm{AF}\end{array}$ & $\begin{array}{c}22.4 \\
4.0 \\
3.9 \\
64.0 \\
1.5 \\
2.6 \\
0.7 \\
0.26 \\
0.28 \\
0.63 \\
0.22 \\
0.08 \\
5 \\
49 \\
27 \\
12\end{array}$ & $\begin{array}{l}\text { Surface Area (Blaine) } \\
\text { Autoclave } \\
\text { Expansion } \\
\text { Initial Set (Gil) } \\
\text { Final Set (Gil) } \\
\text { Air Content } \\
\text { 3-day Strength } \\
\text { 7-day Strength }\end{array}$ & $\begin{array}{c}235 \mathrm{~m}^{2} / \mathrm{kg} \\
-0.03 \% \\
155 \mathrm{~min} \\
205 \mathrm{~min} \\
9 \% \\
1490 \mathrm{psi} \\
2420 \mathrm{psi}\end{array}$ \\
\hline
\end{tabular}




\begin{tabular}{|l|l|}
\hline \multicolumn{2}{|c|}{ Table A-3. Composition of Brine Used as EDX Standard } \\
\hline Component & Concentration $(\mathrm{gm} / 100 \mathrm{ml})$ \\
\hline $\mathrm{NaCl}$, reagent grade & 10.00 \\
\hline $\mathrm{MgCl}_{2} .2 \mathrm{H}_{2} \mathrm{O}$, reagent grade & 19.37 \\
\hline $\mathrm{MgSO}_{4} .7 \mathrm{H}_{2} \mathrm{O}$, reagent grade & 4.00 \\
\hline $\mathrm{KCl}$, reagent grade & 3.00 \\
\hline $\mathrm{CaCl}{ }_{2} .2 \mathrm{H}_{2} \mathrm{O}$, reagent grade & 0.73 \\
\hline $\mathrm{Fe}, 1000 \mathrm{ppm}$ spectral standards & $0.004(40 \mathrm{ppm})$ \\
\hline $\mathrm{Al}, 1000 \mathrm{ppm}$ spectral standards & $0.001(10 \mathrm{ppm})$ \\
\hline $\mathrm{Si}, 1000 \mathrm{ppm}$ spectral standards & $0.025(250 \mathrm{ppm})$ \\
\hline
\end{tabular}


APPENDIX B: DESCRIPTION OF SURFACE DEPOSITS ON DISCS AFTER 60 DAYS EXPOSURE TIME 
B-2 


\section{APPENDIX B: DESCRIPTION OF SURFACE DEPOSITS ON DISCS AFTER}

60 DAYS EXPOSURE TIME

Five-digit sample designator is solution number, salt or non-salt ( $\mathrm{S}$ or $\mathrm{N}$ ), and age (days).

01N60:

Disc was covered with thick white deposits, in clumps and patches of needle-like crystals.

01S60: Looked basically the same as 01 N60 with fewer needles.

02N60: Thick, clear to white crystalline material covered the disc.

02560: Looked the same as $02 \mathrm{~N} 60$, but had less material on the disc.

03N60: The brine solution was cloudy, and the disc had white precipitate only on the outer rim with minimal clear crystalline precipitate on the rest of the surface.

03560: The brine solution was cloudy, and the disc had a thin precipitate layer continuous over its surface.

04N60: A clear-to-white precipitate layer covered entire disc; precipitate on the bottom of the container.

04S60: $\quad$ Looked the same as 04N60.

05N60: The brine solution was cloudy. There was no precipitate on the disc, but there were small cubic crystals in patches on the surface.

05S60: Same as $05 \mathrm{~N} 60$, but fewer patches.

06N60: The brine solution was cloudy. The whole disc was covered with small clear crystalline patches.

06S60: Brine solution was cloudy, and the disc had the same appearance as 06N60.

07N60: Clear brine, and no precipitate on the disc.

07S60: $\quad$ Same as 07N60. 
APPENDIX C: UNCORRECTED AND FQ-CORRECTED CHEMICAL ANALYSIS OF DISCS 
APPENDIX C: UNCORRECTED AND FO-CORRECTED CHEMICAL ANALYSIS OF DISCS

\begin{tabular}{|c|c|c|c|c|c|c|c|c|c|c|}
\hline \multicolumn{11}{|c|}{ Uncorrected } \\
\hline & & & & & SAS & & $10: 29 \mathrm{~T}$ & uesday, & huary 2 & 99365 \\
\hline OBS & COND & AGE & $\mathrm{CaO}$ & $\mathrm{MgO}$ & $\mathrm{SiO}_{2}$ & $\mathrm{SO}_{4}$ & $\mathrm{Cl}$ & $\mathrm{AL}_{2} \mathrm{O}_{3}$ & $\mathrm{Fe}_{2} \mathrm{O}_{3}$ & $\mathrm{Na}_{2} \mathrm{O}$ \\
\hline 52 & CS & 30 & 56.0 & 1.31 & 19.6 & 2.29 & 7.57 & 3.50 & 3.42 & 4.92 \\
\hline 53 & CS & 60 & 56.8 & 1.27 & 18.0 & 2.12 & 7.65 & 3.32 & 3.43 & 4.90 \\
\hline 54 & $\mathrm{CS}$ & 90 & 56.8 & 1.23 & 18.1 & 2.39 & 9.00 & 3.30 & 3.32 & 6.84 \\
\hline 4 & 15 & 30 & 52.9 & 1.67 & 21.4 & 3.19 & 11.32 & 3.85 & 3.97 & 4.96 \\
\hline 5 & is & 60 & 50.8 & 2.13 & 23.0 & 3.41 & 10.64 & 4.53 & 4.65 & 2.08 \\
\hline 6 & is & 90 & 49.2 & 2.46 & 24.5 & 4.14 & 13.46 & 4.81 & 4.94 & 5.28 \\
\hline 10 & $2 S$ & 30 & 52.9 & 1.89 & 22.1 & 2.96 & 12.06 & 4.00 & 4.09 & 5.41 \\
\hline 11 & $2 S$ & 60 & 49.4 & 3.42 & 23.7 & 2.76 & 10.53 & 4.69 & 4.95 & 2.20 \\
\hline 12 & $2 S$ & 90 & 45.1 & 7.61 & 27.5 & 3.04 & 12.55 & 5.58 & 5.10 & 4.15 \\
\hline 16 & 35 & 30 & 57.5 & 1.28 & 18.6 & 3.70 & 7.64 & 3.29 & 3.49 & 5.97 \\
\hline 17 & $3 S$ & 60 & 57.6 & 1.34 & 18.6 & 3.36 & 7.39 & 3.47 & 3.70 & 5.72 \\
\hline 18 & $3 S$ & 90 & 58.4 & 1.35 & 19.9 & 3.99 & 7.62 & 3.72 & 3.58 & 5.80 \\
\hline 22 & $4 S$ & 30 & 57.6 & 1.64 & 24.4 & 5.39 & 3.93 & 4.29 & 4.17 & 0.86 \\
\hline 23 & $4 S$ & 60 & 58.5 & 1.70 & 23.9 & 4.58 & 2.65 & 4.42 & 4.42 & 0.43 \\
\hline 24 & $4 S$ & 90 & 58.5 & 1.76 & 26.0 & 5.52 & 5.52 & 4.94 & 4.42 & 0.44 \\
\hline 28 & $5 S$ & 30 & 59.0 & 1.32 & 20.0 & 1.46 & 7.44 & 3.48 & 3.50 & 2.84 \\
\hline 29 & $5 S$ & 60 & 57.5 & 1.23 & 18.9 & 0.90 & 6.92 & 3.49 & 3.72 & 2.67 \\
\hline 30 & 5S & 90 & 59.5 & 1.30 & 21.1 & 1.08 & 7.73 & 3.86 & 3.56 & 2.89 \\
\hline 34 & $6 S$ & 30 & 59.6 & 1.34 & 20.8 & 7.14 & 1.13 & 3.51 & 3.56 & 0.91 \\
\hline 35 & $6 S$ & 60 & 59.2 & 1.33 & 19.9 & 7.08 & 0.68 & 3.53 & 3.71 & 0.77 \\
\hline 36 & $6 S$ & 90 & 61.2 & 1.43 & 22.2 & 8.43 & 0.70 & 3.97 & 3.75 & 1.43 \\
\hline 40 & $7 S$ & 30 & 63.0 & 1.37 & 21.9 & 2.41 & 1.65 & 3.74 & 3.54 & 0.53 \\
\hline 41 & $7 S$ & 60 & 62.5 & 1.37 & 21.2 & 2.23 & 1.31 & 3.80 & 3.68 & 0.15 \\
\hline 42 & 75 & 90 & 63.9 & 1.38 & 22.6 & 2.55 & 1.19 & 4.17 & 3.73 & 0.12 \\
\hline 46 & $8 S$ & 30 & 62.0 & 1.32 & 20.4 & 2.29 & 1.66 & 3.53 & 3.69 & 0.39 \\
\hline 47 & $8 S$ & 60 & 62.0 & 1.39 & 21.3 & 2.25 & 1.32 & 3.82 & 3.75 & 0.15 \\
\hline 48 & $8 S$ & 90 & 64.5 & 1.58 & 24.7 & 2.75 & 1.49 & 4.60 & 3.78 & 0.33 \\
\hline
\end{tabular}




\begin{tabular}{|c|c|c|c|c|c|c|c|c|c|c|}
\hline \multicolumn{11}{|c|}{ Uncorrected } \\
\hline OBS & COND & AGE & $\mathrm{CaO}$ & $\mathrm{MgO}$ & $\mathrm{SiO}_{2}$ & $\mathrm{SO}_{4}$ & $\mathrm{Cl}$ & $\mathrm{Al}_{2} \mathrm{O}_{3}$ & $\mathrm{Fe}_{2} \mathrm{O}_{3}$ & $\mathrm{Na}_{2} \mathrm{O}$ \\
\hline 49 & $\mathrm{CN}$ & 30 & 61.6 & 1.43 & 20.9 & 2.49 & 0.07 & 3.91 & 3.61 & 0.26 \\
\hline 50 & $\mathrm{CN}$ & 60 & 62.4 & 1.38 & 19.7 & 2.53 & 0.40 & 3.68 & 3.59 & 0.51 \\
\hline 51 & $\mathrm{CN}$ & 90 & 63.2 & 1.50 & 22.5 & 2.74 & 0.05 & 4.42 & 3.61 & 0.33 \\
\hline 1 & $1 N$ & 30 & 54.4 & 1.76 & 22.3 & 3.95 & 9.12 & 4.21 & 4.06 & 2.73 \\
\hline 2 & $1 N$ & 60 & 53.0 & 2.47 & 22.7 & 4.31 & 9.82 & 4.49 & 4.41 & 2.00 \\
\hline 3 & $1 N$ & 90 & 49.3 & 3.34 & 24.3 & 4.62 & 11.78 & 4.91 & 4.60 & 4.50 \\
\hline 7 & $2 N$ & 30 & 55.4 & 2.14 & 21.4 & 3.28 & 8.36 & 4.39 & 4.10 & 2.37 \\
\hline 8 & $2 N$ & 60 & 52.0 & 2.19 & 23.7 & 3.29 & 8.96 & 4.59 & 4.35 & 2.47 \\
\hline 9 & $2 \mathrm{~N}$ & 90 & 50.5 & 3.14 & 26.8 & 3.66 & 10.21 & 5.34 & 4.53 & 2.08 \\
\hline 13 & $3 \mathbf{N}$ & 30 & 58.5 & 1.32 & 18.6 & 3.86 & 6.15 & 3.43 & 3.50 & 4.40 \\
\hline 14 & $3 \mathrm{~N}$ & 60 & 58.7 & 1.43 & 18.7 & 4.49 & 6.03 & 3.60 & 3.50 & 4.22 \\
\hline 15 & $3 N$ & 90 & 59.7 & 1.46 & 20.6 & 4.62 & 5.31 & 4.01 & 3.53 & 3.75 \\
\hline 19 & $4 N$ & 30 & 57.7 & 1.78 & 24.1 & 5.13 & 2.49 & 4.63 & 4.63 & 0.48 \\
\hline 20 & $4 N$ & 60 & 57.1 & 1.63 & 22.5 & 4.92 & 2.36 & 4.28 & 4.20 & 0.44 \\
\hline 21 & $4 N$ & 90 & 58.4 & 1.81 & 26.1 & 5.74 & 1.84 & 5.17 & 4.50 & 0.37 \\
\hline 25 & $5 N$ & 30 & 57.9 & 1.36 & 19.2 & 2.32 & 6.75 & 3.57 & 3.49 & 4.17 \\
\hline 26 & $5 N$ & 60 & 57.8 & 1.36 & 19.2 & 2.08 & 6.21 & 3.59 & 3.48 & 2.72 \\
\hline 27 & $5 N$ & 90 & 60.0 & 1.31 & 20.3 & 2.10 & 6.52 & 3.81 & 3.66 & 3.38 \\
\hline 31 & $6 \mathrm{~N}$ & 30 & 61.1 & 1.55 & 20.3 & 5.94 & 0.35 & 3.75 & 3.55 & 0.42 \\
\hline 32 & $6 \mathrm{~N}$ & 60 & 59.0 & 1.42 & 19.1 & 7.39 & 0.78 & 3.59 & 3.58 & 0.77 \\
\hline 33 & $6 \mathrm{~N}$ & 90 & 61.5 & 1.45 & 21.5 & 8.99 & 0.25 & 4.17 & 3.62 & 0.56 \\
\hline 37 & $7 \mathrm{~N}$ & 30 & 61.6 & 1.54 & 22.1 & 2.83 & 0.67 & 4.10 & 3.59 & 0.16 \\
\hline 38 & $7 \mathrm{~N}$ & 60 & 62.1 & 1.52 & 20.9 & 2.56 & 0.19 & 4.14 & 3.65 & 0.17 \\
\hline 39 & $7 \mathrm{~N}$ & 90 & 62.3 & 1.50 & 22.5 & 2.68 & 0.05 & 4.38 & 3.68 & 0.11 \\
\hline 43 & $8 \mathrm{~N}$ & 30 & 63.7 & 1.51 & 21.7 & 2.73 & 0.06 & 4.05 & 3.72 & 0.11 \\
\hline 44 & $8 \mathrm{~N}$ & 60 & 62.2 & 1.50 & 21.9 & 2.84 & 0.20 & 3.97 & 3.64 & 0.25 \\
\hline 45 & $8 \mathrm{~N}$ & 90 & 63.6 & 1.60 & 24.1 & 2.80 & 0.05 & 4.74 & 3.77 & 0.18 \\
\hline
\end{tabular}




\begin{tabular}{|c|c|c|c|c|c|c|c|c|c|c|}
\hline \multicolumn{11}{|c|}{ CORRECTED BY Fe-RATIO METHOD } \\
\hline OBS & COND & AGE & $\mathrm{CaO}$ & $\mathrm{MgO}$ & $\mathrm{SiO}_{2}$ & $\mathrm{SO}_{4}$ & $\mathrm{Cl}$ & $\mathrm{Al}_{2} \mathrm{O}_{3}$ & $\mathrm{Na}_{2} \mathrm{O}$ & $\mathrm{CF}$ \\
\hline 25 & $\mathrm{CS}$ & 30 & 55.51 & 1.30 & 19.43 & 2.27 & 7.50 & 3.47 & 4.88 & 0.991 \\
\hline 26 & CS & 60 & 56.14 & 1.26 & 17.79 & 2.10 & 7.56 & 3.28 & 4.84 & 0.988 \\
\hline 27 & $\mathrm{CS}$ & 90 & 58.00 & 1.26 & 18.48 & 2.44 & 9.19 & 3.37 & 6.98 & 1.021 \\
\hline 1 & $1 S$ & 30 & 45.17 & 1.43 & 18.27 & 2.72 & 9.67 & 3.29 & 4.24 & 0.854 \\
\hline 2 & $1 S$ & 60 & 37.03 & 1.55 & 16.77 & 2.49 & 7.76 & 3.30 & 1.52 & 0.729 \\
\hline 3 & $1 S$ & 90 & 33.76 & 1.69 & 16.81 & 2.84 & 9.24 & 3.30 & 3.62 & 0.686 \\
\hline 4 & $2 S$ & 30 & 43.85 & 1.57 & 18.32 & 2.45 & 10.00 & 3.32 & 4.48 & 0.829 \\
\hline 5 & $2 S$ & 60 & 33.83 & 2.34 & 16.23 & 1.89 & 7.21 & 3.21 & 1.51 & 0.685 \\
\hline 6 & $2 S$ & 90 & 29.98 & 5.06 & 18.28 & 2.02 & 8.34 & 3.71 & 2.76 & 0.665 \\
\hline 7 & $3 S$ & 30 & 55.85 & 1.24 & 18.07 & 3.59 & 7.42 & 3.20 & 5.80 & 0.971 \\
\hline 8 & $3 S$ & 60 & 52.77 & 1.23 & 17.04 & 3.08 & 6.77 & 3.18 & 5.24 & 0.916 \\
\hline 9 & $3 S$ & 90 & 55.30 & 1.28 & 18.84 & 3.78 & 7.22 & 3.52 & 5.49 & 0.947 \\
\hline 10 & $4 S$ & 30 & 46.83 & 1.33 & 19.84 & 4.38 & 3.19 & 3.49 & 0.70 & 0.813 \\
\hline 11 & $4 S$ & 60 & 44.87 & 1.30 & 18.33 & 3.51 & 2.03 & 3.39 & 0.33 & 0.767 \\
\hline 12 & $4 S$ & 90 & 44.87 & 1.35 & 19.94 & 4.23 & 4.23 & 3.79 & 0.34 & 0.767 \\
\hline 13 & $5 S$ & 30 & 57.15 & 1.28 & 19.37 & 1.41 & 7.21 & 3.37 & 2.75 & 0.969 \\
\hline 14 & $5 S$ & 60 & 52.40 & 1.12 & 17.22 & 0.82 & 6.31 & 3.18 & 2.43 & 0.911 \\
\hline 15 & $5 S$ & 90 & 56.66 & 1.24 & 20.09 & 1.03 & 7.36 & 3.68 & 2.75 & 0.952 \\
\hline 16 & $6 S$ & 30 & 56.75 & 1.28 & 19.81 & 6.80 & 1.08 & 3.34 & 0.87 & 0.952 \\
\hline 17 & $6 S$ & 60 & 54.09 & 1.22 & 18.18 & 6.47 & 0.62 & 3.23 & 0.70 & 0.914 \\
\hline 18 & $6 S$ & 90 & 55.32 & 1.29 & 20.07 & 7.62 & 0.63 & 3.59 & 1.29 & 0.904 \\
\hline 19 & $7 S$ & 30 & 60.33 & 1.31 & 20.97 & 2.31 & 1.58 & 3.58 & 0.51 & 0.958 \\
\hline 20 & $7 S$ & 60 & 57.57 & 1.26 & 19.53 & 2.05 & 1.21 & 3.50 & 0.14 & 0.921 \\
\hline 21 & $7 S$ & 90 & 58.08 & 1.25 & 20.54 & 2.32 & 1.08 & 3.79 & 0.11 & 0.909 \\
\hline 22 & $8 S$ & 30 & 56.96 & 1.21 & 18.74 & 2.10 & 1.53 & 3.24 & 0.36 & 0.919 \\
\hline 23 & $8 S$ & 60 & 56.05 & 1.26 & 19.26 & 2.03 & 1.19 & 3.45 & 0.14 & 0.904 \\
\hline 24 & $8 S$ & 90 & 57.85 & 1.42 & 22.15 & 2.47 & 1.34 & 4.13 & 0.30 & 0.897 \\
\hline
\end{tabular}




\begin{tabular}{|c|c|c|c|c|c|c|c|c|c|c|}
\hline \multicolumn{11}{|c|}{ OXIDE ANALYSIS CORRECTED BY Fe-RATIO METHOD } \\
\hline OBS & COND & AGE & $\mathrm{CaO}$ & MgO & $\mathrm{SiO}_{2}$ & $\mathrm{SO}_{4}$ & $\mathrm{Cl}$ & $\mathrm{Al}_{2} \mathrm{O}_{3}$ & $\mathrm{Na}_{2} \mathrm{O}$ & CF \\
\hline 25 & $\mathrm{CN}$ & 30 & 61.43 & 1.43 & 20.84 & 2.48 & 0.07 & 1.90 & 0.26 & 0.997 \\
\hline 26 & $\mathrm{CN}$ & 60 & 62.57 & 1.38 & 19.75 & 2.54 & 0.40 & 3.69 & 0.51 & 1.003 \\
\hline 27 & $\mathrm{CN}$ & 90 & 63.02 & 1.50 & 22.44 & 2.73 & 0.05 & 4.41 & 0.33 & 0.997 \\
\hline 1 & $1 N$ & 30 & 48.24 & 1.56 & 19.77 & 3.50 & 8.09 & 3.73 & 2.42 & 0.887 \\
\hline 2 & $1 N$ & 60 & 43.27 & 2.02 & 18.53 & 3.52 & 8.02 & 3.67 & 1.63 & 0.816 \\
\hline 3 & $1 \mathrm{~N}$ & 90 & 38.58 & 2.61 & 19.02 & 3.62 & 9.22 & 3.84 & 3.52 & 0.783 \\
\hline 4 & $2 \mathrm{~N}$ & 30 & 48.64 & 1.88 & 18.79 & 2.88 & 7.34 & 3.85 & 2.08 & 0.878 \\
\hline 5 & $2 \mathrm{~N}$ & 60 & 43.03 & 1.81 & 19.61 & 2.72 & 7.42 & 3.80 & 2.04 & 0.828 \\
\hline 6 & $2 \mathrm{~N}$ & 90 & 40.13 & 2.50 & 21.30 & 2.91 & 8.11 & 4.24 & 1.65 & 0.795 \\
\hline 7 & $3 N$ & 30 & 60.17 & 1.36 & 19.13 & 3.97 & 6.33 & 3.53 & 4.53 & 1.029 \\
\hline 8 & $3 \mathrm{~N}$ & 60 & 60.38 & 1.47 & 19.23 & 4.62 & 6.20 & 3.70 & 4.34 & 1.029 \\
\hline 9 & $3 \mathbf{N}$ & 90 & 60.88 & 1.49 & 21.01 & 4.71 & 5.42 & 4.09 & 3.82 & 1.020 \\
\hline 10 & $4 \mathbf{N}$ & 30 & 44.86 & 1.38 & 18.74 & 3.99 & 1.94 & 3.60 & 0.37 & 0.778 \\
\hline 11 & $4 N$ & 60 & 48.94 & 1.40 & 19.29 & 4.22 & 2.02 & 3.67 & 0.38 & 0.857 \\
\hline 12 & $4 N$ & 90 & 46.72 & 1.45 & 20.88 & 4.59 & 1.47 & 4.14 & 0.30 & 0.800 \\
\hline 13 & $5 N$ & 30 & 59.72 & 1.40 & 19.81 & 2.39 & 6.96 & 3.68 & 4.30 & 1.032 \\
\hline 14 & $5 N$ & 60 & 59.79 & 1.41 & 19.86 & 2.15 & 6.42 & 3.71 & 2.81 & 1.034 \\
\hline 15 & $5 \mathrm{~N}$ & 90 & 59.02 & 1.29 & 19.97 & 2.07 & 6.41 & 3.75 & 3.32 & 0.984 \\
\hline 16 & $6 N$ & 30 & 61.96 & 1.57 & 20.59 & 6.02 & 0.35 & 3.80 & 0.43 & 1.014 \\
\hline 17 & $6 N$ & 60 & 59.33 & 1.43 & 19.21 & 7.43 & 0.78 & 3.61 & 0.77 & 1.006 \\
\hline 18 & $6 \mathrm{~N}$ & 90 & 61.16 & 1.44 & 21.38 & 8.94 & 0.25 & 4.15 & 0.56 & 0.994 \\
\hline 19 & $7 N$ & 30 & 61.77 & 1.54 & 22.16 & 2.84 & 0.67 & 4.11 & 0.16 & 1.003 \\
\hline 20 & $7 N$ & 60 & 61.25 & 1.50 & 20.61 & 2.52 & 0.19 & 4.08 & 0.17 & 0.986 \\
\hline 21 & $7 N$ & 90 & 60.95 & 1.47 & 22.01 & 2.62 & 0.05 & 4.28 & 0.11 & 0.978 \\
\hline 22 & $8 \mathrm{~N}$ & 30 & 61.65 & 1.46 & 21.00 & 2.64 & 0.06 & 3.92 & 0.11 & 0.968 \\
\hline 23 & $8 \mathrm{~N}$ & 60 & 61.52 & 1.48 & 21.66 & 2.81 & 0.20 & 3.93 & 0.25 & 0.989 \\
\hline 24 & $8 \mathrm{~N}$ & 90 & 60.73 & 1.53 & 23.01 & 2.67 & 0.05 & 4.53 & 0.17 & 0.955 \\
\hline
\end{tabular}




\section{DISTRIBUTION}

\section{Federal Agencies}

US Department of Energy (6)

Office of Civilian Radioactive Waste Management

Attn: Deputy Director, RW-2

Associate Director, RW-10/50

Office of Program and

Resources Management

Office of Contract Business

Management

Director, $R W-22$

Analysis and Verification

Division

Associate Director, RW-30

Office of Systems and

Compliance

Associate Director, RW-40

Office of Storage and

Transportation

Director, $\mathrm{RW}-4 / 5$

Office of Strategic Planning

and International Programs

Office of External Relations

Forrestal Building

Washington, DC 20585

US Department of Energy

Albuquerque Operations office

Attn: National Atomic Museum Library

PO Box 5400

Albuquerque, NM 87185-5400

US Department of Energy (4)

WIPP Project Integration office

Attn: W.J. Arthur III

L.W. Gage

P.J. Higgins

D.A. Olona

PO Box 5400

Albuquerque, NM 87115-5400

US Department of Energy (2)

WIPP Project Integration Satellite

Office

Attn: R. Batra

R. Becker

PO Box 3090, Mail Stop 525

Carlsbad, NM 88221-3090

US Department of Energy

Research \& Waste Management Division Attn: Director

PO Box E

Oak Ridge, TN 37831
US Department of Energy (3)

WIPP Project Site Office (Carlsbad)

Attn: V. Daub

J. Lippis

J.A. Mewhinney

PO Box 3090

Car1sbad, NM 88221-3090

US Department of Energy

Attn: E. Young

Room E-178

GAO/RCED/GTN

Washington, DC 20545

US Department of Energy

Office of Environmental Restoration and Waste Management

Attn: J. Lytle, EM-30, Trevion II

Washington, DC 20585-0002

US Department of Energy (3)

Office of Environmental Restoration and Waste Management

Attn: M. Frei, EM-34, Trevion II

Washington, DC 20585-0002

US Department of Energy

Office of Environmental Restoration and Waste Management

Attn: S. Schneider, EM-342, Trevion II

Washington, DC 20585-0002

US Department of Energy (2)

Office of Environment, Safety and Health

Attn: C. Borgstrom, EH -25

R. Pelletier, EH-231

Washington, DC 20585

US Department of Energy (2)

Idaho Operations office

Fuel Processing and Waste

Management Division

785 DOE Place

Idaho Falls, ID 83402

US Environmental Protection

Agency (2)

Radiation Protection Programs

Attn: M. Oge

ANR -460

Washington, DC 20460 
US Geological Survey (2)

Water Resources Division

Attn: R. Livingston

4501 Indian School NE

Suite 200

Albuquerque, NM 87110

US Nuclear Regulatory Commission Division of Waste Management

Attn: H. Marson

Mail Stop 4-H-3

Washington, DC 20555

\section{Boards}

Defense Nuclear Facilities Safety Board

Attn: D. Winters

625 Indiana Ave. NW, Suite 700

Washington, DC 20004

Nuclear Waste Technical Review

Board (2)

Attn: Chairman

$$
\text { S.J.S. Parry }
$$

1100 Wilson Blvd., Suite 910

Arlington, VA 22209-2297

Advisory Committee on Nuclear Waste

Nuclear Regulatory Commission

Attn: R. Major

7920 Norfolk Ave.

Bethesda, MD 20814

\section{State Agencies}

Environmental Evaluation Group (3)

Attn: Library

7007 Wyoming NE

Suite F-2

Albuquerque, NM 87109

NM Bureau of Mines and Mineral

Resources

Socorro, NM 87801

NM Energy, Minerals, and Natural

Resources Department

Attn: Library

2040 S. Pacheco

Santa Fe, NM 87505

NM Environment Department (3)

Secretary of the Environment

Attn: J. Espinosa

1190 St. Francis Drive

Santa Fe, NM 87503-0968
NM Environment Department

WIPP Project Site

Attn: P. McCasland

PO Box 3090

Carlsbad, NM 88221

\section{Laboratories/Corporations}

Battelle Pacific Northwest

Laboratories

Attn: R.E. Westerman

MSIN P8-44

Battelle Blvd.

Richland, WA 99352

INTERA, Inc.

Attn: G.A. Freeze

1650 University NE, Suite 300

Albuquerque, NM 87102

INTERA, Inc .

Attn: J.F. Pickens

6850 Austin Center Blvd., Suite 300

Austin, TX 78731

INTERA, Inc .

Attn: W. Stensrud

PO Box 2123

Carlsbad, NM 88221

IT Corporation

Attn: R.F. McKinney

Regional Office

5301 Central NE, Suite 700

Albuquerque, NM 87108

Los Alamos National Laboratory

Attn: B. Erdal, INC-12

PO Box 1663

Los Alamos, NM 87544

$\mathrm{RE} / \mathrm{SPEC}$, Inc.

Attn: W. Coons

4775 Indian School NE, Suite 300

Albuquerque, NM 87110-3927

$\mathrm{RE} / \mathrm{SPEC}$, Inc.

Attn: J.L. Ratigan

PO Box 725

Rapid City, SD 57709

Southwest Research Institute (2)

Center for Nuclear Waste Regulatory

Analysis

Attn: P.K. Nair

6220 Culebra Road

San Antonio, TX 78228-0510 
SAIC

Attn: H.R. Pratt

10260 Campus Point Dr.

San Diego, CA 92121

SAIC (2)

Attn: M. Davis

J. Tollison

2109 Air Park Rd. SE

Albuquerque, NM 87106

Tech Reps Inc. (3)

Attn: J. Chapman

C. Crawford

T. Peterson

5000 Marble NE, Suite 222

Albuquerque, NM 87110

TRW Environmental Safety Systems Attn: L. Wildman

2650 Park Tower Dr., Suite 1300

Vienna, VA 22180-7306

Waterways Experiment Station (2)

Attn: L.D. Wakeley

3909 Halls Ferry Rd.

Vicksburg, MS 39180-5927

Westinghouse Electric Corporation (5)

Attn: Library

C. Cox

L. Fitch

B.A. Howard

R. Kehrman

PO Box 2078

Carlsbad, NM 88221

Westinghouse-Savannah River

Technology Center (4)

Attn: N. Bibler

J.R. Harbour

M.J. Plodinec

G.G. Wicks

Aiken, SC 29802

\section{National Academy of Sciences, WIPP Panel}

Howard Adler

Oak Ridge Associated Universities

Medical Sciences Division

PO Box 117

Oak Ridge, TN 37831-0117

Ina Alterman

Board on Radioactive Waste

Management, GF456

2101 Constitution Ave.

Washington, DC 20418
Fred M. Ernsberger

1325 NW Tenth Ave.

Gainsville, FL 32605

John D. Bredehoeft

Western Region Hydrologtst

Water Resources Division

US Geological Survey (M/S 439)

345 Middlefield Road

Menlo Park, CA 94025

Rodney C. Ewing

Department of Geology

University of New Mexico

Albuquerque, NM 87131

Charles Fairhurst

Department of Civil and Mineral

Engineering

University of Minnesota

500 Pillsbury Dr. SE

Minneapolis, MN 55455-0220

B. John Garrick

PLG Incorporated

4590 MacArthur Blvd., Suite 400

Newport Beach, CA 92660-2027

Leonard F. Konikow

US Geological Survey

431 National Center

Reston, VA 22092

Carl A. Anderson, Director

Board on Radioactive Waste Management

National Research Council

HA 456

2101 Constitution Ave. NW

Washington, DC 20418

Jeremiah O'Driscoll

Jody Incorporated

505 Valley Hill Drive

Atlanta, GA 30350

Christopher G. Whipple

ICF Kaiser Engineers

1800 Harrison St., 7th Floor

Oakland, CA 94612-3430

\section{Individuals}

P. Drez

8816 Cherry Hills Rd. NE

Albuquerque, NM 87111 
K. Lickliter

400-C 8th St. SW

Tacoma, WA 98439

D.W. Powers

Star Route Box 87

Anthony, TX 79821

\section{Universities}

University of Missouri-Rolla

Department of Nuclear Engineering

Attn: N. Tsoulfanidis

102 Fulton Hall

Rolla, MO 65401-0249

University of New Mexico

Geology Department

Attn: Library

141 Northrop Hall

Albuquerque, NM 87131

University of Washington

College of Ocean \& Fishery Sciences

Attn: G.R. Heath

583 Henderson Hall $\mathrm{HN}-15$

Seattle, WA 98195

\section{Libraries}

Thomas Brannigan Library

Attn: D. Dresp

106 W. Hadley St.

Las Cruces, NM 88001

Government Publications Department

Zimmerman Library

University of New Mexico

Albuquerque, NM 87131

New Mexico Junior College

Pannell Library

Attn: R. Hill

Lovington Highway

Hobbs, NM 88240

New Mexico State Library

Attn: N. McCallan

325 Don Gaspar

Santa Fe, NM 87503

New Mexico Tech

Martin Speere Memorial Library

Campus Street

Socorro, NM 87810
WIPP Public Reading Room

Carlsbad Public Library

$101 \mathrm{~S}$. Halagueno St.

Carlsbad, NM 88220

\section{Foreign Addresses}

Studiecentrum Voor Kernenergie

Centre d'Énergie Nucléaire

Attn: A. Bonne

SCK/CEN Boeretang 200

B-2400 Mol, BELGIUM

Atomic Energy of Canada, Ltd

Whiteshell Laboratories

Attn: B. Goodwin

M. Stevens

D. Wushke

Pinawa, Manitoba, CANADA ROE 1 LO

Francois Chenevier (2)

ANDRA

Route du Panorama Robert Schumann

B.P. 38

92266 Fontenay-aux-Roses, Cedex

FRANCE

Jean-Pierre Olivier

OECD Nuclear Energy Agency

Division of Radiation Protection and

Waste Management

38, Boulevard Suchet

75016 Paris, FRANCE

Claude Sombret

Centre d'Études Nucléaires de la

Vallee Rhone CEN/VALRHO

S.D.H.A. B.P. 171

30205 Bagnols-Sur-Ceze, FRANCE

Commissariat a L'Energie Atomique

Attn: D. Alexandre

Centre' d'Études de Cadarache

13108 Saint Paul Lez Durance Cedex

FRANCE

Bundesanstalt für Geowissenschaften und Rohstoffe

Attn: M. Langer

Postfach 510153

D-30631 Hannover, GERMANY

Bundesministerium für Forschung und Technologie

Postfach 200706

5300 Bonn 2, GERMANY 
Institut für Tieflagerung (2)

Attn: K. Kuhn

Theodor-Heuss-Strasse 4

D-3300 Braunschweig, GERMANY

Gesellschaft für Anlagen und

Reaktorsicherheit (GRS) (2)

Attn: B. Baltes

W. Muller

Schwertnergasse 1

D-50667 Cologne, GERMANY

Physikalisch-Technische Bundesanstalt Attn: P. Brenneke

Postfach 3345

D-3300 Braunschweig, GERMANY

Shingo Tashiro

Japan Atomic Energy Research Inst.

Toka1-Mura, Ibaraki-Ken, 319-11

JAPAN

Netherlands Energy Research

Foundation ECN

Attn: L.H. Vons

3 Westerduinweg

PO Box 1

1755 ZG Petten

THE NETHERLANDS

Svensk Kärnbränsleforsorjning $A B$

Attn: F. Karlsson

Project KBS (Kärnbrănslesakerhet)

Box 5864

S-102 48 Stockholm

SWEDEN

Nationale Genossenschaft für die

Lagerung radioaktiver Abfalle (2)

Attn: S. Vomvoris

P. Zuidema

Hardstrasse 73

$\mathrm{CH}-5430$ Wettingen

SWITZERLAND

AEA Technology

Attn: J.H. Rees

D5W/29 Culham Laboratory

Abington, Oxfordshire 0X14 3DB

UNITED KINGDOM

AEA Technology

Attn: W.R. Rodwell

044/A31 Winfrith Technical Centre

Dorchester, Dorset DT2 8DH

UNITED KINGDOM
AEA Technology

Attn: J.E. Tinson

B4244 Harwell Laboratory

iidcot, Oxfordshire OXI1 ORA

UNITED KINGDOM

D.R. Knowles

British Nuclear Fuels, plc

Risley, Warrington, Cheshire WA3 6AS

1002607 UNITED KINGDOM

\begin{tabular}{|c|c|c|}
\hline & & Internal \\
\hline MS & Org & \\
\hline 0827 & $\overline{1502}$ & P.J. Hommert \\
\hline 0127 & 4511 & D.P. Garber \\
\hline 0724 & 6000 & D.L. Hartley \\
\hline 1324 & 6115 & P.B. Davies \\
\hline 1324 & 6115 & staff (15) \\
\hline 0750 & 6118 & J.L. Krumhans 1 \\
\hline 7050 & 6118 & S.J. Lambert \\
\hline 1320 & 6119 & E.J. Nowak \\
\hline 1320 & 6119 & Staff (7) \\
\hline 1332 & 6121 & J.R. Tillerson \\
\hline 332 & 6121 & Staff (7) \\
\hline 1335 & 6303 & S.Y. Pickering \\
\hline 335 & 6303 & W.D. Weart \\
\hline 335 & 6305 & S.A. Goldstein \\
\hline 1335 & 6305 & A.R. Lappin \\
\hline 1341 & 6306 & A.L Stevens \\
\hline 1328 & 6342 & D.R. Anderson \\
\hline 1328 & 6342 & Staff $(20)$ \\
\hline 1395 & 6343 & V.H. Slaboszewicz \\
\hline 1395 & 6343 & Staff (2) \\
\hline 1341 & 6345 & R.C. Lincoln \\
\hline 1341 & 6345 & Staff (9) \\
\hline 1341 & 6347 & D.R. Schafer \\
\hline 1341 & 6348 & J.T. Holmes \\
\hline 1341 & 6348 & Staff (4) \\
\hline 1343 & 6351 & R.E. Thompson \\
\hline 1330 & 6352 & G.M. Gerstner-Miller \\
\hline 1330 & 6352 & WIPP Central Files (10) \\
\hline 0899 & 7141 & Technical Library (5) \\
\hline 0619 & 7151 & Technical Publications \\
\hline 0100 & $7613-2$ & $\begin{array}{l}\text { Document Processing for } \\
\text { DOE/OSTI (10) }\end{array}$ \\
\hline 18 & $3-2$ & Central Technical File \\
\hline
\end{tabular}



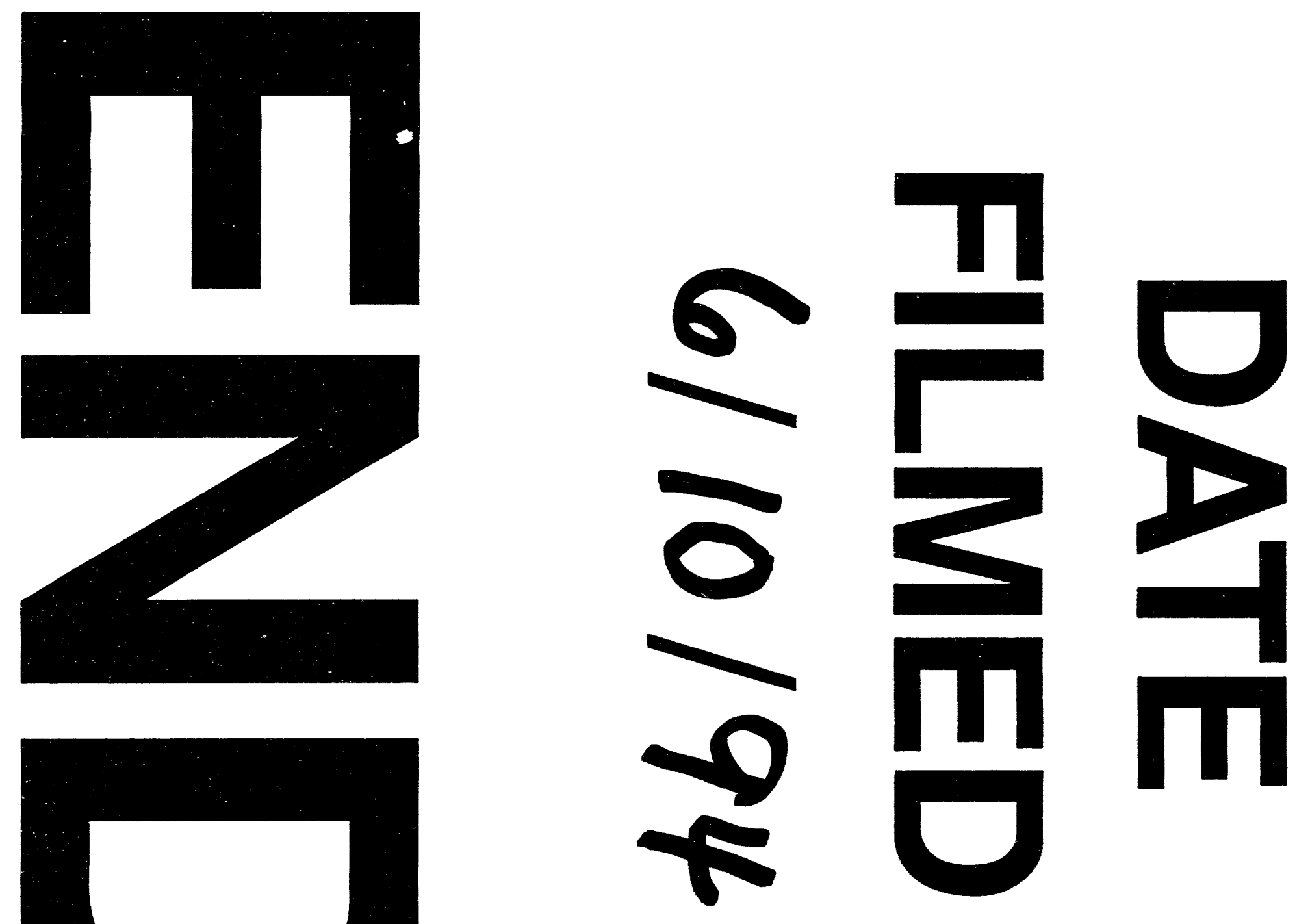
